\title{
Probabilistic Evaluation of CPT-based Seismic Soil Liquefaction Potential: Towards the Integration of Interpretive Structural Modeling and Bayesian Belief Network
}

Mahmood Ahmad ( $\square$ ahmadm@mail.dlut.edu.cn)

University of Engineering and Technology, Peshawar, Pakistan https://orcid.org/0000-0002-1139-1831

Xiao-Wei Tang

Dalian University of Technology

Feezan Ahmad

Dalian University of Technology

Nima Pirhadi

Southwest Petroleum University

\section{Xusheng Wan}

Southwest Petroleum University

Kuang Cheng

Hebei University

\section{Research Article}

Keywords: Bayesian belief network, cone penetration test, earthquake-induced liquefaction, interpretive structural modeling, data mining

Posted Date: April 26th, 2021

DOI: https://doi.org/10.21203/rs.3.rs-245487/v1

License: (c) (i) This work is licensed under a Creative Commons Attribution 4.0 International License.

Read Full License 


\title{
Probabilistic Evaluation of CPT-based Seismic Soil Liquefaction Potential: Towards the Integration of Interpretive Structural Modeling and Bayesian Belief Network
}

Mahmood Ahmad ${ }^{1}$, Xiao-Wei Tang ${ }^{2, *}$, Feezan Ahmad ${ }^{2}$, Nima Pirhadi ${ }^{3}$, Xusheng Wan ${ }^{3}$ and Kuang Cheng 4

1 Department of Civil Engineering, University of Engineering and Technology Peshawar (Bannu Campus), Bannu 28100, Pakistan; ahmadm@mail.dlut.edu.cn (M. A.)

2 State Key Laboratory of Coastal and Offshore Engineering, Dalian University of Technology, Dalian 116024, China; tangxw@dlut.edu.cn (X.-W.T.); engrfeezanktk@hotmail.com (F.A.)

3 Southwest Petroleum University, Chengdu, China; nima.pirhadi@swpu.edu.cn (N.P.); xinyanwanxxusheng@163.com (X.W.)

4 College of Civil Engineering \& Architecture, Hebei University, Baoding 071002, China kchengdut@163.com (K.C.)

* Correspondence should be addressed to Xiao-Wei Tang; tangxw@dlut.edu.cn (X.-W.T.)

\begin{abstract}
This paper proposes a probabilistic graphical model that integrates interpretive structural modeling (ISM) and Bayesian belief network (BBN) approaches to predict CPT-based soil liquefaction potential. In this study, an ISM approach was employed to identify relationships between influence factors, whereas BBN approach was used to describe the quantitative strength of their relationships using conditional and marginal probabilities. The proposed model combines major causes, such as soil, seismic and site conditions, of seismic soil liquefaction at once. To demonstrate the application of the propose framework, the paper elaborates on each phase of the BBN framework, which is then validated with historical empirical data. In context of the rate of successful prediction of liquefaction and non-liquefaction events, the proposed probabilistic graphical model is proven to be more effective, compared to logistic regression, support vector machine, random forest and naïve Bayes methods. This research also interprets sensitivity analysis and the most probable explanation of seismic soil liquefaction appertaining to engineering perspective.
\end{abstract}

Keywords: Bayesian belief network; cone penetration test; earthquake-induced liquefaction; interpretive structural modeling; data mining.

\section{Introduction}

Determination of soil liquefaction potential is a fundamental step for seismic-induced hazard mitigation. In the last few decades, numerous researchers have attempted to 
present different methods that are based on in situ tests to predict the soil liquefaction potential, e.g. Seed and Idriss 1981; Seed and Idriss 1971; Robertson and Wride 1998; Youd and Idriss 2001; Juang et al. 2003; Moss et al. 2006; Idriss and Boulanger 2006; such as standard penetration test (SPT), cone penetration test (CPT), and techniques for shear wave velocity $\left(V_{s}\right)$. The findings of the cone penetration test (CPT) have been adapted by many researchers from in situ tests as the basis for evaluating the liquefaction potential of the test method (e.g. Juang et al. 2003; Youd and Idriss 2001). A main significance of the CPT is almost continuous information given throughout the depth of the explored soil strata. The CPT is also known to be much accurate and repeatable than other types of in situ test methods.

Artificial intelligence (AI) techniques as for example random forest (Kohestani et al. 2015), adaptive neuro-fuzzy inference system (ANFIS) (Xue and Yang 2013), relevance vector machine (RVM) (Samui 2007), artificial neural network (ANN) (Goh 1996; Juang et al. 2003; Samui et al. 2011) and support vector machine (SVM) (Goh and Goh 2007; Oommen et al. 2010; Pal 2006; Samui et al. 2011) models were developed to predict liquefaction potential based on in situ test database. Over conventional modeling techniques, the primary strength of AI techniques is their process of capturing nonlinear and complex correlation between system variables without having to presume the correlations between different variables of input and output. In the scope of assessing the occurrence of liquefaction, these techniques may be trained to learn the relationship between soil, site, and earthquake characteristics with the potential for liquefaction, needing no prior knowledge of the form of the relation. Mostly models are black box, i.e., a relationship between inputs and output is not present in these models.

The Bayesian Belief Network (BBN) is a graphical model that enables a set of variables to be probabilistically connected (Pearl 1988). To address cause-effect relationships and complexities, BBN may provide an effective structure. BBN not only provides sequential inference (from causes to results) but also reverse inference (from results to causes). The benefits of BBNs include the following compared to other methods: (1) BBN achieves a combination of qualitative and quantitative analysis; (2) BBN allows reversal inference (from results to causes) and it is simple to obtain the ranking of factors affecting the casualties; (3) BBN has a good learning ability; (4) allows data to be combined with domain knowledge; and (5) Even with very limited sample sizes, BBN can demonstrate good prediction accuracy. Furthermore, its application in seismic liquefaction potential on CPT-based in-situ tests data is comparatively less e.g. (Ahmad et al. 2019a; Ahmad et al. 2020a; Ahmad et al. 2020b).

The contributions of this paper are fourfold: (1) this article discusses the interdependence of different CPT-based seismic soil liquefaction variables, whereas the Bayesian Belief Network (BBN) approach uses conditional and marginal probabilities to describe the quantitative strength of their relationships; (2) the performance of the proposed model is comparatively assessed with four traditional seismic soil liquefaction 
modeling algorithms (logistic regression, SVM, RF, and Naïve Bayes); (3) the sensitivity analysis of predictor variables is presented owing to know the effect of input factors on the liquefaction potential; and (4) the most probable explanation (MPE) of seismic soil liquefaction with reference to engineering perspective is presented.

This article consists of six major sections. Next section presents resarch methodology, Section 3 is devoted to the probabilistic graphical model development and evaluation measures. Results and discussion are presented in Section 4. Finally, in the last part, conclusions and future work are set out.

\section{Research Methodology}

\subsection{Interpretive Structural Modeling}

Interpretive structural modeling (ISM) is a well-established technique that describes a situation or a problem to classify the relationships between particular issues. A collection of different elements that are directly and indirectly connected are organized into a structured comprehensive model in this approach (Sage 1977; Warfield 1974). The model thus created depicts the structure of a complex problem or issue in a carefully constructed pattern that implies graphics and words (Raj and Attri 2011; Ravi and Shankar 2005; Shankar et al. 2003). Different researchers have increasingly used this technique to depict the interrelationships between various elements relevant to the issues. The ISM approach includes the identification of variables that are important to the issue or problem. Then a contextually relevant subordinate relationship is identified. On the basis of a pair wise comparison of variables, after the contextual relationship has been determined, a structural self-interaction matrix (SSIM) is defined. After this, SSIM is converted into a reachability matrix (RM) and its transitivity is examined. A matrix model is obtained after transitivity embedding is complete. Then, the element partitioning and a structural model extraction called ISM are derived.

\subsection{Bayesian Belief Network}

Bayesian Belief Networks (BBN) is a graphical network of causal connections between different nodes. In BBN models, the network structure is a directed acyclic graph (DAG) that graphically represents the logical relationship between nodes, and the conditional probability of quantifying the strength of this relationship is the network parameter (Castelletti and Soncini-Sessa 2007; Ghribi and Masmoudi 2013; Masmoudi et al. 2019). The network structure and network parameter can be obtained via expert knowledge (Joseph et al. 2010; Nadkarni and Shenoy 2001) or training from data (Kabir et al. 2015). A sample BBN model is shown in Figure 1, where node $X$ is the parent node of the child nodes $Y$ and $Z$, and node $Y$ is the parent node of the child node $Z$. Edges are represented by the arrows between the two nodes. 


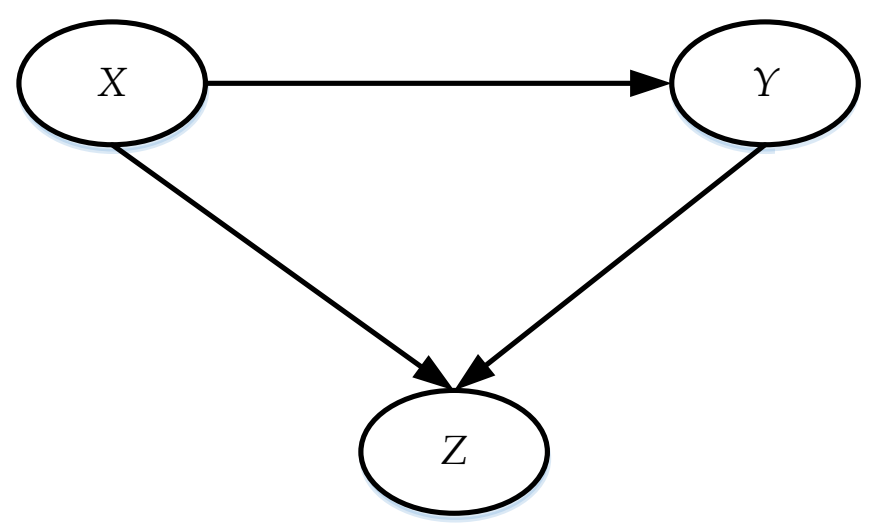

Figure 1. A simple Bayesian Network structure.

The joint probability of Bayesian belief networks can be defined as the product of each node's edge probability:

$$
P(X, Y, Z)=P(X) \times P(Y \mid X) \times P(Z \mid X, Y)
$$

where $P(X)$ is the prior probability that is the conditional probability without parent nodes, $P(Y \mid X)$ is the conditional probability that is the occurrence probability of $Y$ under the $X$ conditions, $P(Z \mid X, Y)$ is the conditional probability that is the occurrence probability of $Z$ under the $X$ and $Y$ conditions. Figure 2 presents the graphical flow of the approach. 


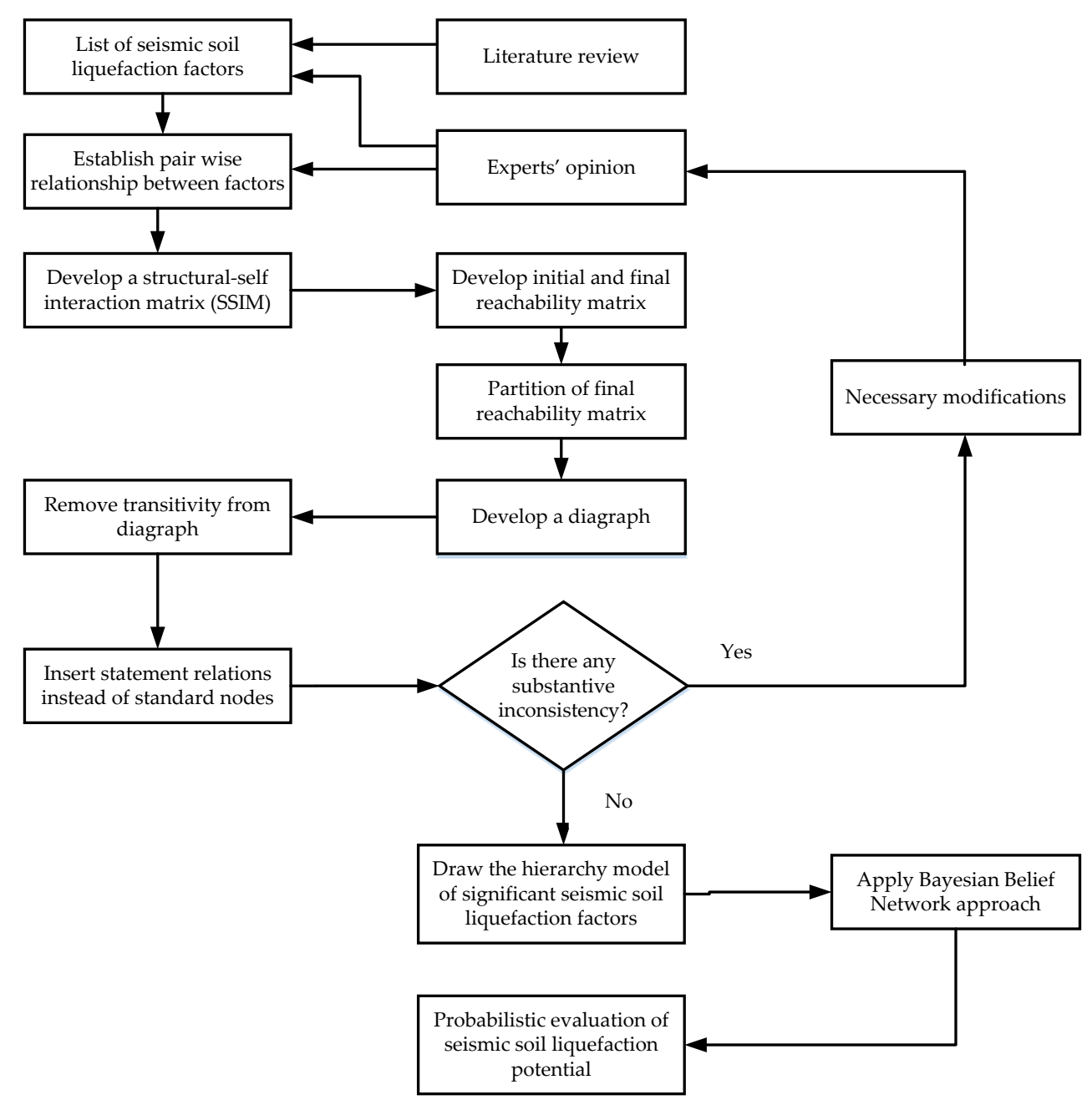

Figure 2. The process outline of the methodology of research used in the present study.

\section{Development of Probabilistic Graphical Model and Evaluation Measures}

\subsection{Data set and Predictor Variables}

The data set used in this analysis was on the basis of the revised version of the CPT case history records collected by Boulanger and Idriss (Boulanger and Idriss 2014). The entire data set consists of 253 cases with a soil behaviour type index, $I_{c}<2.6$, of which 180 are liquefied cases, another 71 are non-liquefied cases and the remaining 2 are doubtful cases (margin between liquefied and non-liquefied) in this research work. These case histories are derived from CPT measurements of 17 sites and field performance reports of major earthquakes (see Table $\mathrm{A}$ in appendix A). Liquefaction is caused by seismic parameters, site conditions, and soil properties that include a varied range of factors. So nine critical factors or variables used for the possible evaluation of liquefaction are chosen, namely earthquake magnitude $(M) \mathrm{F}_{1}$, peak ground acceleration $\left(a_{\max }, \mathrm{g}\right) \mathrm{F}_{2}$, fines content $(F C, \%) \mathrm{F}_{3}$, equivalent clean sand penetration resistance $\left(q_{c 1 N c s}\right)$ $\mathrm{F}_{4}$, soil behaviour type index $\left(I_{c}\right) \mathrm{F}_{5}$, vertical effective stress $\left(\sigma_{v}^{\prime}, \mathrm{kPa}\right) \mathrm{F}_{6}$, groundwater 
table depth $\left(D_{w}, \mathrm{~m}\right) \mathrm{F}_{7}$, depth of soil deposit $\left(D_{s}, \mathrm{~m}\right) \mathrm{F}_{8}$, thickness of soil layer $\left(T_{s}, \mathrm{~m}\right) \mathrm{F}_{9}$, and output is liquefaction potential, $\mathrm{F}_{10}$ in this paper according to Okoli and Schabram (Okoli and Schabram 2010) and Tranfield et al. (Tranfield et al. 2003). For more details of CPT case histories, viewers may refer to the Boulanger and Idriss reference (Boulanger and Idriss 2014). The statistical characteristics of the data set used in this study, such as minimum (Min.), maximum (Max.), mean, standard deviation (SD) and variation coefficient (COV), are shown in Table 1. Figure 3 explains the frequency histograms of measured parameters. For instance, 105 data samples were measured in the range of 2-4 with regard to the $D_{s}$ parameter.

Table 1. Statistical aspects of the dataset.

\begin{tabular}{llllllllll}
\hline $\begin{array}{l}\text { Statistical } \\
\text { parameters }\end{array}$ & $\boldsymbol{M}$ & $\begin{array}{l}\boldsymbol{a}_{\max } \\
\mathbf{( g )}\end{array}$ & $\begin{array}{l}\boldsymbol{F} \boldsymbol{( \% )} \\
\mathbf{( \% )}\end{array}$ & $\boldsymbol{q}_{c 1 N c s}$ & $\boldsymbol{I}_{c}$ & $\begin{array}{l}\boldsymbol{\sigma}_{v}^{\prime} \\
(\mathbf{k P a})\end{array}$ & $\begin{array}{l}\boldsymbol{D}_{\boldsymbol{w}} \\
(\mathbf{m})\end{array}$ & $\begin{array}{l}\boldsymbol{D}_{s} \\
(\mathbf{m})\end{array}$ & $\boldsymbol{T}_{s}(\mathbf{m})$ \\
\hline Min. & 5.9 & 0.09 & 0 & 16.1 & 1.16 & 19 & 0.2 & 1.4 & 0.3 \\
Max. & 9 & 0.84 & 85 & 311.9 & 2.59 & 147 & 7.2 & 11.8 & 6.5 \\
Mean & 6.98 & 0.32 & 17.71 & 93.89 & 1.96 & 57.62 & 2.04 & 4.44 & 1.83 \\
SD & 0.55 & 0.15 & 19.27 & 38.06 & 0.29 & 24.55 & 1.21 & 1.96 & 1.22 \\
COV & 0.08 & 0.46 & 1.09 & 0.41 & 0.15 & 0.43 & 0.59 & 0.44 & 0.67 \\
\hline
\end{tabular}
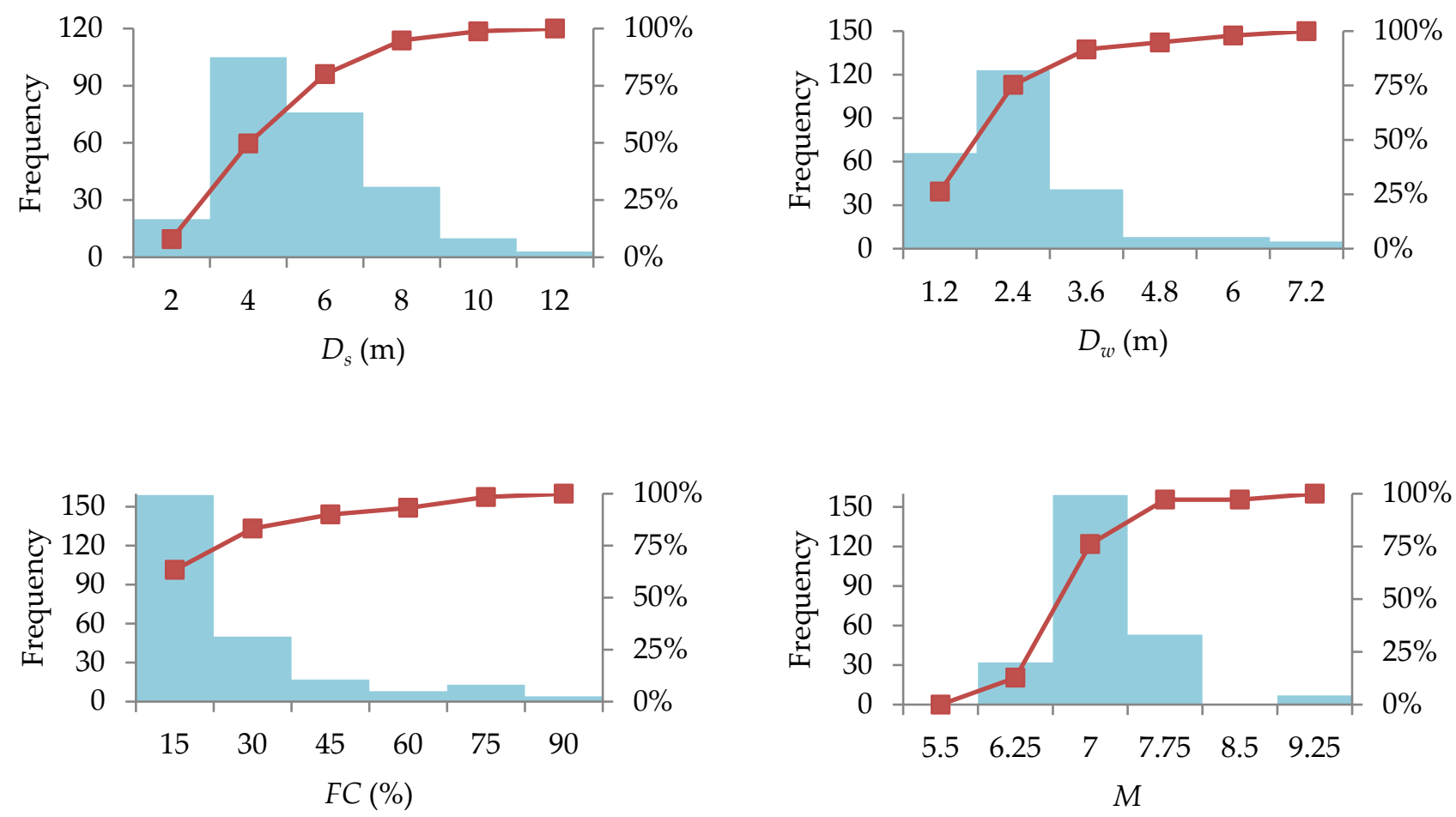

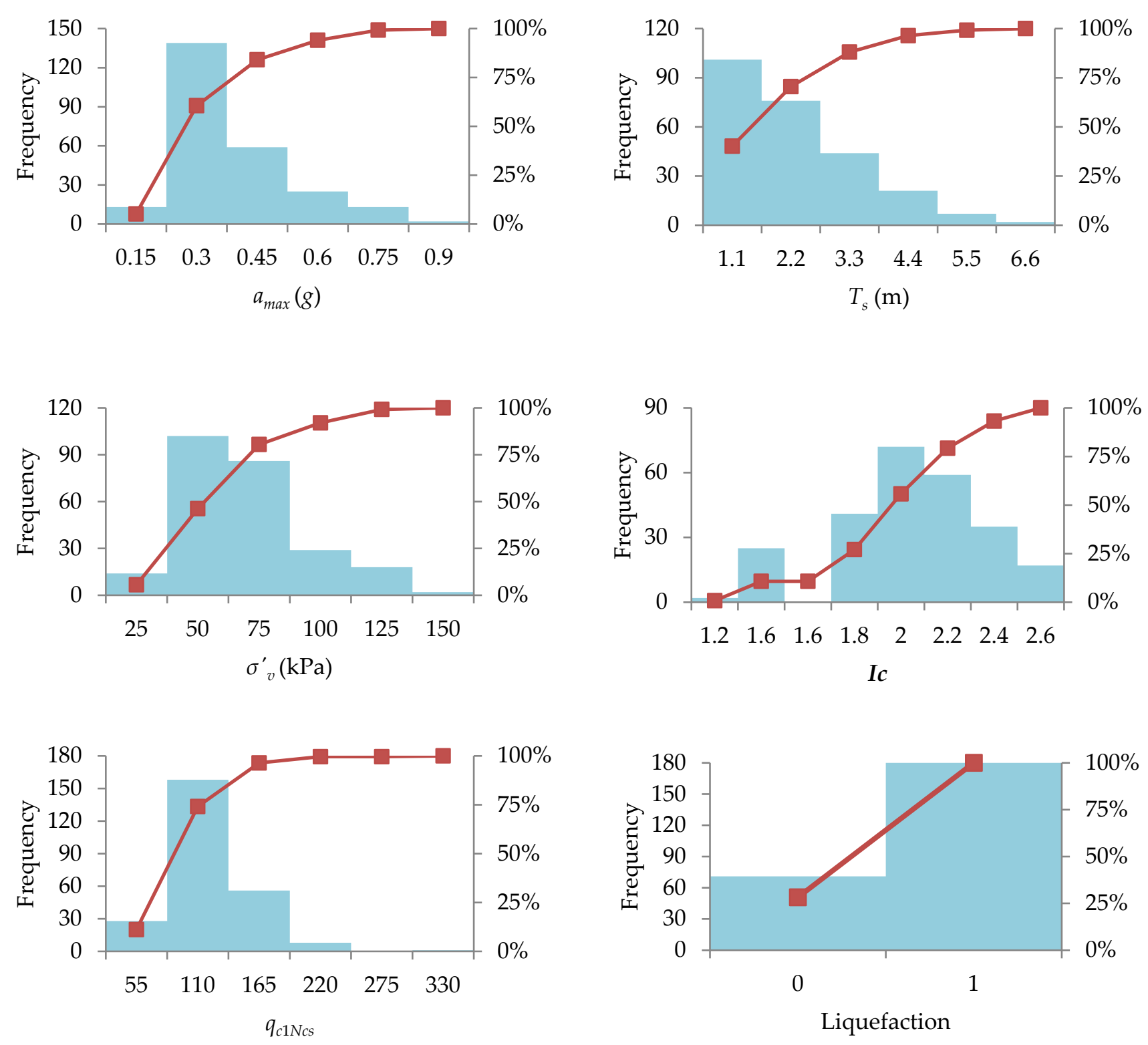

Figure 3. Frequency histograms of measured parameters

Previous studies (Ahmad et al. 2019a; Ahmad et al. 2019b; Hu et al. 2015; Zhang 1998) showed detail understanding about the variables' selection and discretization. BBN has a good capability to deal with discrete variables, but is weak in continuous variables processing, so the nine significant factors and output (liquefaction potential, $F_{10}$ ) require to be transformed into discrete values before the propose model is constructed accordance to the possible factor range and expert knowledge, as shown in Table 2. The output " 0 " represents non-liquefied case while " 1 " represents liquefied case is shown in Figure 3.

Table 2. Grading specifications for seismic soil liquefaction variables. 


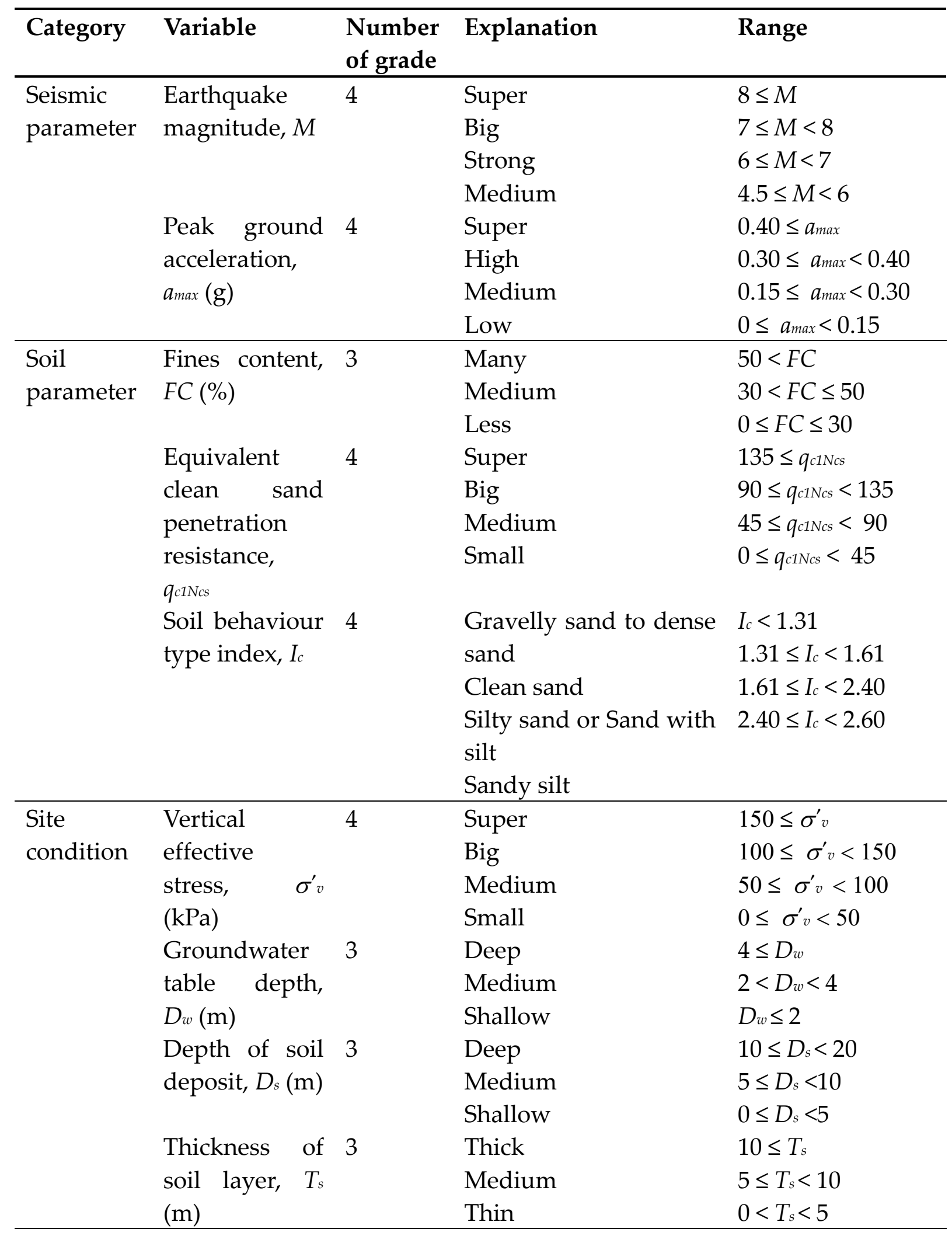

3.2 Probabilistic Graphical Model for CPT-based Seismic Soil Liquefaction Potential 
The data set has been divided into training and testing datasets according to statistical aspects for example mean, maximum, minimum, etc. to build the models:

- To build the models, a training data set is required. In this study, $201(80 \%)$ CPT case histories of the data were used by authors for training set.

- To predict the performance of the established models, a testing data set is required. In this study, the remaining $50(20 \%)$ CPT case histories data is considered to be a testing data set.

ISM technique suggests the use of domain or expert knowledge in the creation of the contextual relationships between the nine significant variables and contextual relationships are ultimately analyzed by field experts who have approved and represented by SSIM (see Table 3).

Table 3. SSIM for seismic soil liquefaction variables.

\begin{tabular}{ccccccccccc}
\hline $\mathrm{V}_{1}$ & $\mathrm{~V}_{2}$ & $\mathrm{~V}_{3}$ & $\mathrm{~V}_{4}$ & $\mathrm{~V}_{5}$ & $\mathrm{~V}_{6}$ & $\mathrm{~V}_{7}$ & $\mathrm{~V}_{8}$ & $\mathrm{~V}_{9}$ & $\mathrm{~V}_{10}$ & $\mathrm{~V}_{i}$ \\
\hline & $\mathrm{V}$ & $\mathrm{O}$ & $\mathrm{O}$ & $\mathrm{O}$ & $\mathrm{O}$ & $\mathrm{O}$ & $\mathrm{O}$ & $\mathrm{O}$ & $\mathrm{V}$ & $\mathrm{V}_{1}$ \\
& & $\mathrm{O}$ & $\mathrm{O}$ & $\mathrm{A}$ & $\mathrm{O}$ & $\mathrm{O}$ & $\mathrm{O}$ & $\mathrm{O}$ & $\mathrm{V}$ & $\mathrm{V}_{2}$ \\
& & $\mathrm{~V}$ & $\mathrm{~V}$ & $\mathrm{O}$ & $\mathrm{O}$ & $\mathrm{O}$ & $\mathrm{O}$ & $\mathrm{V}$ & $\mathrm{V}_{3}$ \\
& & & $\mathrm{~A}$ & $\mathrm{~A}$ & $\mathrm{~A}$ & $\mathrm{~A}$ & $\mathrm{O}$ & $\mathrm{V}$ & $\mathrm{V}_{4}$ \\
& & & & $\mathrm{~A}$ & $\mathrm{O}$ & $\mathrm{O}$ & $\mathrm{O}$ & $\mathrm{V}$ & $\mathrm{V}_{5}$ \\
& & & & & $\mathrm{~A}$ & $\mathrm{~A}$ & $\mathrm{O}$ & $\mathrm{V}$ & $\mathrm{V}_{6}$ \\
& & & & & & $\mathrm{O}$ & $\mathrm{O}$ & $\mathrm{V}$ & $\mathrm{V}_{7}$ \\
& & & & & & & $\mathrm{O}$ & $\mathrm{V}$ & $\mathrm{V}_{8}$ \\
& & & & & & & & $\mathrm{~V}$ & $\mathrm{~V}_{9}$ \\
& & & & & & & & & & $\mathrm{~V}_{10}$ \\
\hline
\end{tabular}

$\mathrm{V}$ - row variable influences the column variable.

A- column variable influences the row variable.

O- no relationship among the row and column variables.

In the next phase, the SSIM is changed to a binary matrix for seismic soil liquefaction factors, called the initial reachability matrix (IRM), by exchanging the original symbols with 1 or 0 , as shown in Table B1 in Appendix B. When the IRM is obtained, the transitivity property is verified to get the final matrix of reachability (FRM). The transitivity check is the basic principle of the ISM methodology that if the ' $a$ ' variable is related to the ' $b$ ' variable and the ' $b$ ' variable is related to the ' $c$ ' variable, the ' $a$ ' variable is ultimately correlated with the ' $c$ ' variable. The new entries that are labeled as ' 1 ' are implied after transitivity checking. The FRM with rank, driving and dependence powers is shown in Appendix B of Table B2. The variables used to derive multilevel hierarchy structure levels, along with their reachability set $\left(S_{r}\right)$, antecedent set $\left(S_{a}\right)$, and intersection set $\left(S_{i}\right)$, are shown in Table B3-B7 in Appendix B. The findings showed that there are five partition levels which are as follows: 


$$
\mathrm{L}_{1}=\left\{\mathrm{F}_{10}\right\} ; \mathrm{L}_{2}=\left\{\mathrm{F}_{2}, \mathrm{~F}_{4}, \mathrm{~F}_{9}\right\} ; \mathrm{L}_{3}=\left\{\mathrm{F}_{1}, \mathrm{~F}_{5}\right\} ; \mathrm{L}_{4}=\left\{\mathrm{F}_{3}, \mathrm{~F}_{6}\right\} ; \mathrm{L}_{5}=\left\{\mathrm{F}_{7}, \mathrm{~F}_{8}\right\} .
$$

The liquefaction potential multilevel hierarchy structure is formed from the FRM. The transitivity relations between two variables, such as the direct links between the $D_{s}$ and the $D_{w}$ with liquefaction potential, are eliminated because the $D_{s}$ and the $D_{w}$ will influence the liquefaction potential through vertical effective stress. In the next phase, there is no conceptual inconsistency in the structural model so the ISM is developed for the soil liquefaction potential (see Figure 4). There is a restriction of no links between skipping-level nodes in the ISM model (for example, FC and liquefaction potential).

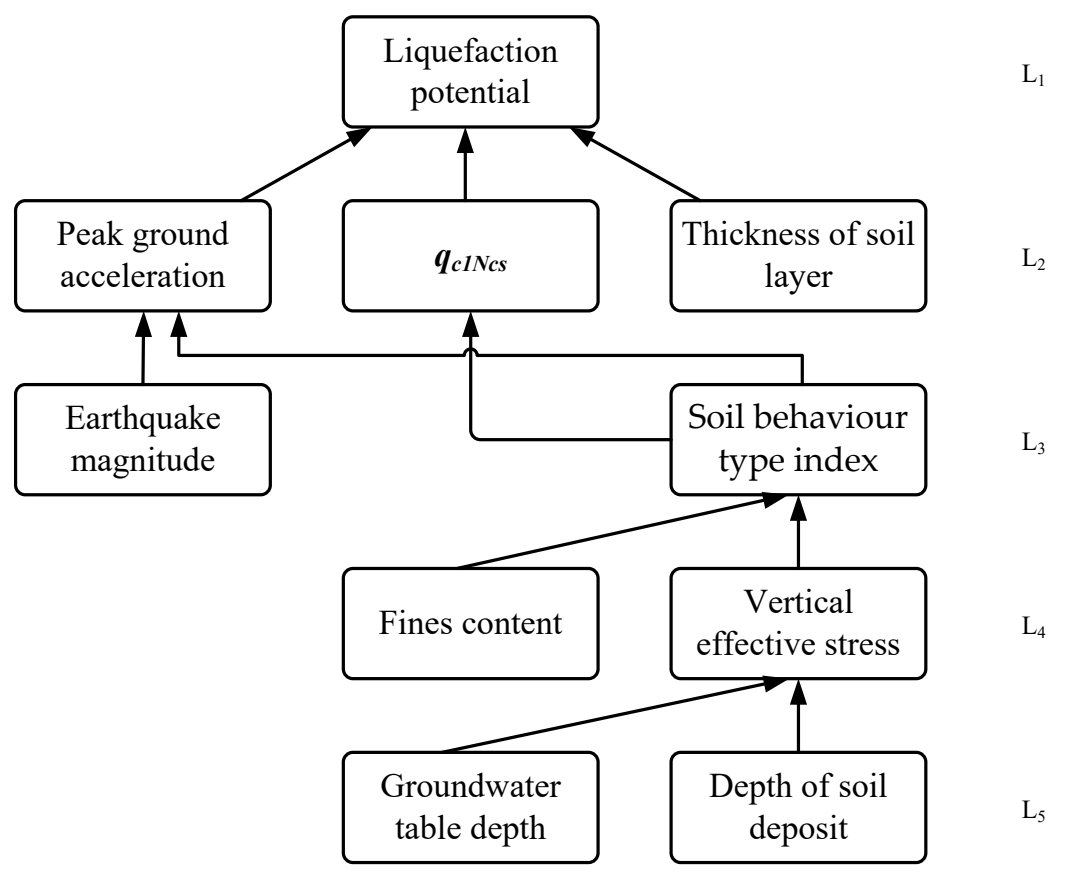

Figure 4. Interpretive structural modeling of liquefaction potential.

It can be seen that peak ground acceleration (PGA), $q_{c 1 N c s}$ and soil layer thickness $\left(T_{s}\right)$ in the second level are directly influencing factors of liquefaction potential, while $D_{s}$ and the $D_{w}$ in the last level are the most vibrant factors that form the basis of the ISM hierarchy. In other levels, fines content, vertical effective stress, soil behaviour type index and earthquake magnitude are the indirect factors influencing the liquefaction potential.

A network model with an unknown structure or insufficient knowledge can be hard to create directly. To fix this issue, Liao et al. [37] used ISM to develop a network diagram, which they specifically used as a BBN for evaluating outsourcing risk. This approach effectively processes the relationships between variables by splitting the problem into different levels, making the overall structure clear and easy to understand and ensuring 
a deeper understanding of the problem. In order to facilitate constructing a BBN diagram, the final network diagram obtained from ISM defines the interdependent relationships between factors at the same level or between two levels. The model system is built directly into Netica software distributed by Norsys Software Corp to define the quantitative intensity of their relationships. The graphical presentation is shown in Figure 5.

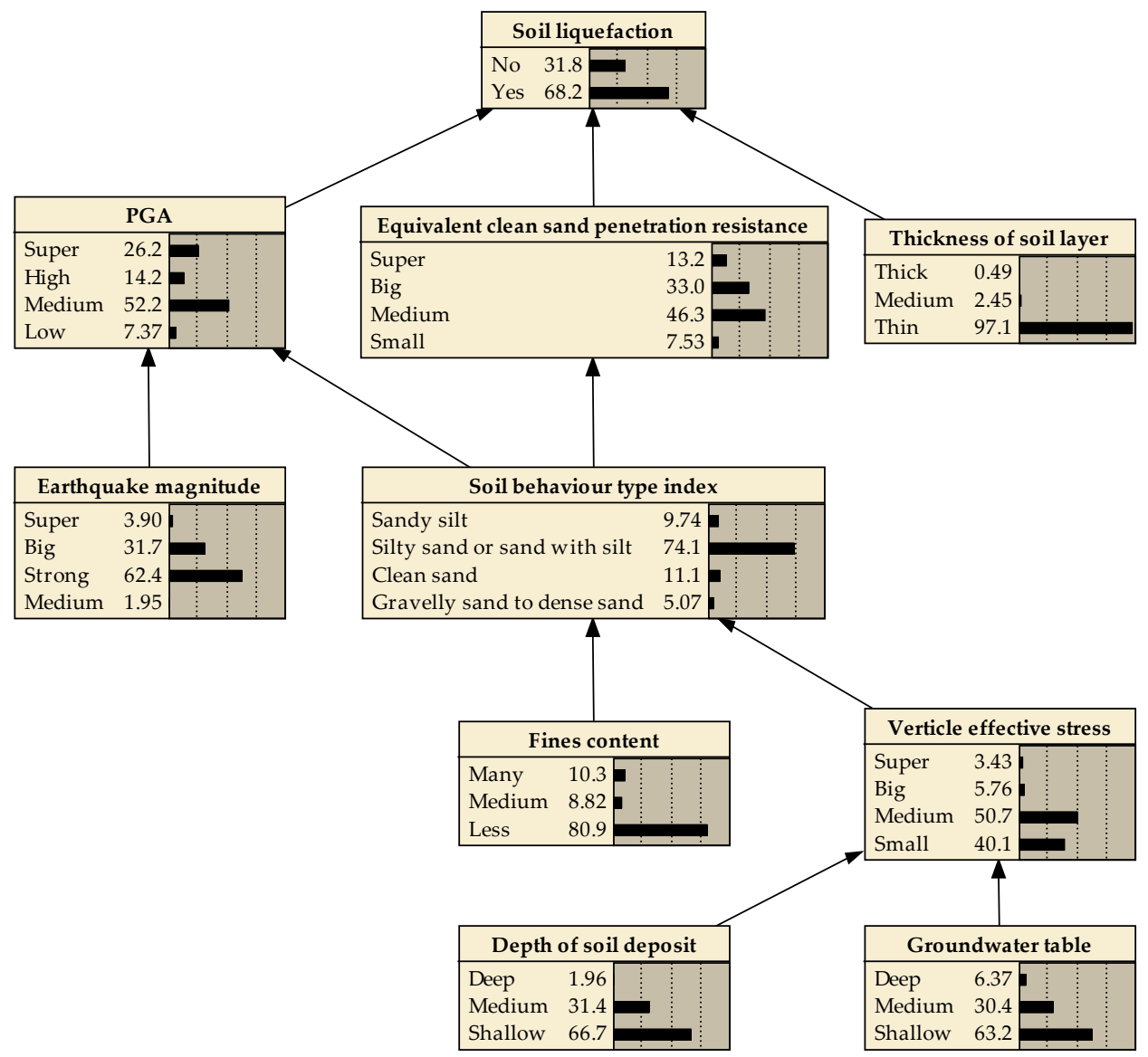

Figure 5. Liquefaction potential graphical model.

\section{Evaluation and Prediction}

To evaluate the propose model, It was compared with some other techniques using measurements of scalar performance.

4.1 Compared Methods

The proposed model was compared with other prediction methods, including four other methods widely used (Table 4).

Table 4. Prediction methods compared

\begin{tabular}{ll} 
Method & Description \\
\hline Logistic & Logistic regression is a probability evaluation process focused on \\
\hline
\end{tabular}




\begin{tabular}{ll}
\hline Method & Description \\
\hline Regression (LR) & $\begin{array}{l}\text { the calculation of maximum probability (Hosmer and Lemeshow } \\
\text { 2000). }\end{array}$ \\
\hline $\begin{array}{l}\text { Support Vector } \\
\text { Machine (SVM) }\end{array}$ & $\begin{array}{l}\text { SVM, based on mathematical learning models is one of the most } \\
\text { robust prediction methods (Vapnik 1995). SVM training method } \\
\text { computes a model that assigns new examples to one category or } \\
\text { the other, making it a non-probabilistic binary linear classifier, } \\
\text { given a set of training examples, each marked as belonging to one } \\
\text { of two categories. }\end{array}$ \\
\hline $\begin{array}{l}\text { Random Forest } \\
\text { (RF) }\end{array}$ & $\begin{array}{l}\text { Random forest (Breiman 2001) is a meta-learning scheme that } \\
\text { integrates many independently developed base classifiers and } \\
\text { participates in a voting process to obtain a prediction for the final } \\
\text { class. }\end{array}$ \\
\hline Naive Bayes (NB) & $\begin{array}{l}\text { Naive Bayes (John and Langley 1995) assumes that the predictive } \\
\text { variables, provided the target/dependent variable, are conditionally } \\
\text { independent. }\end{array}$ \\
\hline
\end{tabular}

\subsection{Evaluation Measures}

Four scalar measurements are used, i.e., accuracy, precision, recall and F-measure. There are four possible outcomes for a single prediction in the binary class scenario, i.e., liquefaction and non-liquefaction. The correct classification is true negative (TN) and true positive (TP). If the output is incorrectly predicted as negative, a false positive (FP) occurs, If the result is wrongly labeled as negative, a false negative (FN) occurs. Accuracy $(a c c)$ is a calculation of the total number of accurate predictions. The acc's value is calculated as follows:

$$
a c c=\frac{T P+T N}{T P+F N+F P+T N}
$$

Precision refers to the proportion of correctly classified positive cases and recall is referred to as the portion of correctly classified actual positive cases. A pair of contradictory measures is precision ( $p r)$ and recall $(r e)$. The $p r$ is generally large, while $r e$ is not large, or vice versa. The confusion matrix (see Table 5) can be used to evaluate these as:

$$
\begin{aligned}
& p r=\frac{T P}{T P+F P} \text { or } \frac{T N}{F N+T N} \\
& r e=\frac{T P}{T P+F N} \text { or } \frac{T N}{F P+T N}
\end{aligned}
$$




$$
F-\text { score }=\frac{2 \times p r \times r e}{p r+r e}
$$

The best value for the F-score is 1 and the worst value is 0 .

Table $5.2 \times 2$ confusion matrix.

\begin{tabular}{llll}
\hline & & \multicolumn{2}{c}{ Predicted class } \\
\cline { 3 - 4 } & & Yes & No \\
\hline \multirow{2}{*}{ Actual class } & Yes & TP & FN \\
& No & FP & TN \\
\hline
\end{tabular}

\section{Results and Discussion}

\subsection{Comparative Performance of Multiple Learners Based on Test Dataset}

The prediction results of the proposed model, i.e., BBN-ISM, LR, SVM, RF and NB models, were obtained on the test set. Subsequently, as shown in Table 6, each model's confusion matrix was calculated. The values on the main diagonal indicated the correctly predicted number of samples. The $a c c, p r, r e$, and F-score were determined on the basis of Equations (2)-(5) mentioned in Table 7, based on Table 6. The results in Table 7 show that the developed model gave the best predictive performance, with much higher acc than other models (from $4 \%$ to $16 \%$ improvement over other models). The performance of the LR model is just secondary to the proposed model. In addition, the accuracy degrees of BBN-ISM were found highest and up to $78 \%$, followed by $72 \%$ accuracy of the LR model. Comparing their values of $p r$, re, and F-score, BBN-ISM model performed better than LR, SVM, RF and NB models. Therefore, the rank was BBN-ISM $>$ LR $>$ SVM $>$ NB based on their overall prediction results.

Table 6. Confusion matrices results for testing dataset.

\begin{tabular}{|c|c|c|c|c|c|c|c|c|c|c|}
\hline \multicolumn{11}{|c|}{ Model } \\
\hline \multirow{3}{*}{ True } & BBN & ISM & & & & & & & & \\
\hline & \multicolumn{10}{|c|}{ Predicted } \\
\hline & No & Yes & No & Yes & No & Yes & No & Yes & No & Yes \\
\hline No & 9 & 5 & 7 & 8 & 7 & 8 & 7 & 8 & 6 & 9 \\
\hline Yes & 6 & 30 & 5 & 30 & 6 & 29 & 7 & 28 & 10 & 25 \\
\hline
\end{tabular}

Table 7. Performance evaluation of testing dataset.

\begin{tabular}{cccccccc}
\hline \multirow{2}{*}{ Model } & & \multicolumn{3}{c}{ Liquefaction } & \multicolumn{3}{c}{ Non-liquefaction } \\
\cline { 3 - 8 } & $\boldsymbol{a}(\mathbf{\%})$ & $\boldsymbol{r}$ & $\boldsymbol{p}$ & F-score & $\boldsymbol{r}$ & $\boldsymbol{p}$ & F - score \\
\hline BBN-ISM & $\mathbf{7 8}$ & 0.833 & $\mathbf{0 . 8 5 7}$ & $\mathbf{0 . 8 4 5}$ & $\mathbf{0 . 6 4 3}$ & $\mathbf{0 . 6 0 0}$ & $\mathbf{0 . 6 2 1}$ \\
LR & 74 & $\mathbf{0 . 8 5 7}$ & 0.789 & 0.822 & 0.467 & 0.583 & 0.519 \\
\hline
\end{tabular}




\begin{tabular}{cccccccc}
\hline \multirow{2}{*}{ Model } & & \multicolumn{3}{c}{ Liquefaction } & \multicolumn{3}{c}{ Non-liquefaction } \\
\cline { 3 - 8 } & $\boldsymbol{a}(\mathbf{\%})$ & $\boldsymbol{r}$ & $\boldsymbol{p}$ & F-score & $\boldsymbol{r}$ & $\boldsymbol{p}$ & F - score \\
\hline SVM & 72 & 0.829 & 0.784 & 0.806 & 0.467 & 0.538 & 0.500 \\
RF & 70 & 0.800 & 0.778 & 0.789 & 0.467 & 0.500 & 0.483 \\
Naïve Bayes & 62 & 0.714 & 0.735 & 0.725 & 0.400 & 0.375 & 0.387 \\
\hline
\end{tabular}

\subsection{Most Probable Explanation}

Using the Netica function to decide which situation is most probable to cause soil liquefaction potential, the most probable explanation (MPE) can be found and the established model can be used to obtain the most probable explanation. For instance, if the soil liquefaction is "yes" as shown in Figure 6, the function "most probable explanation" is used to identify the set that is most probable to cause "soil liquefaction" which is [peak ground acceleration = medium, equivalent clean sand penetration resistance $=$ medium, thickness of soil layer $=$ thin, earthquake magnitude $=$ strong, soil behaviour type index $=$ silty sand, fines content $=$ less, vertical effective stress $=$ small, groundwater table $=$ shallow, and depth of soil deposit $=$ shallow $]$. This shows explicitly that the set is indeed well associated with the judgment of engineering. 


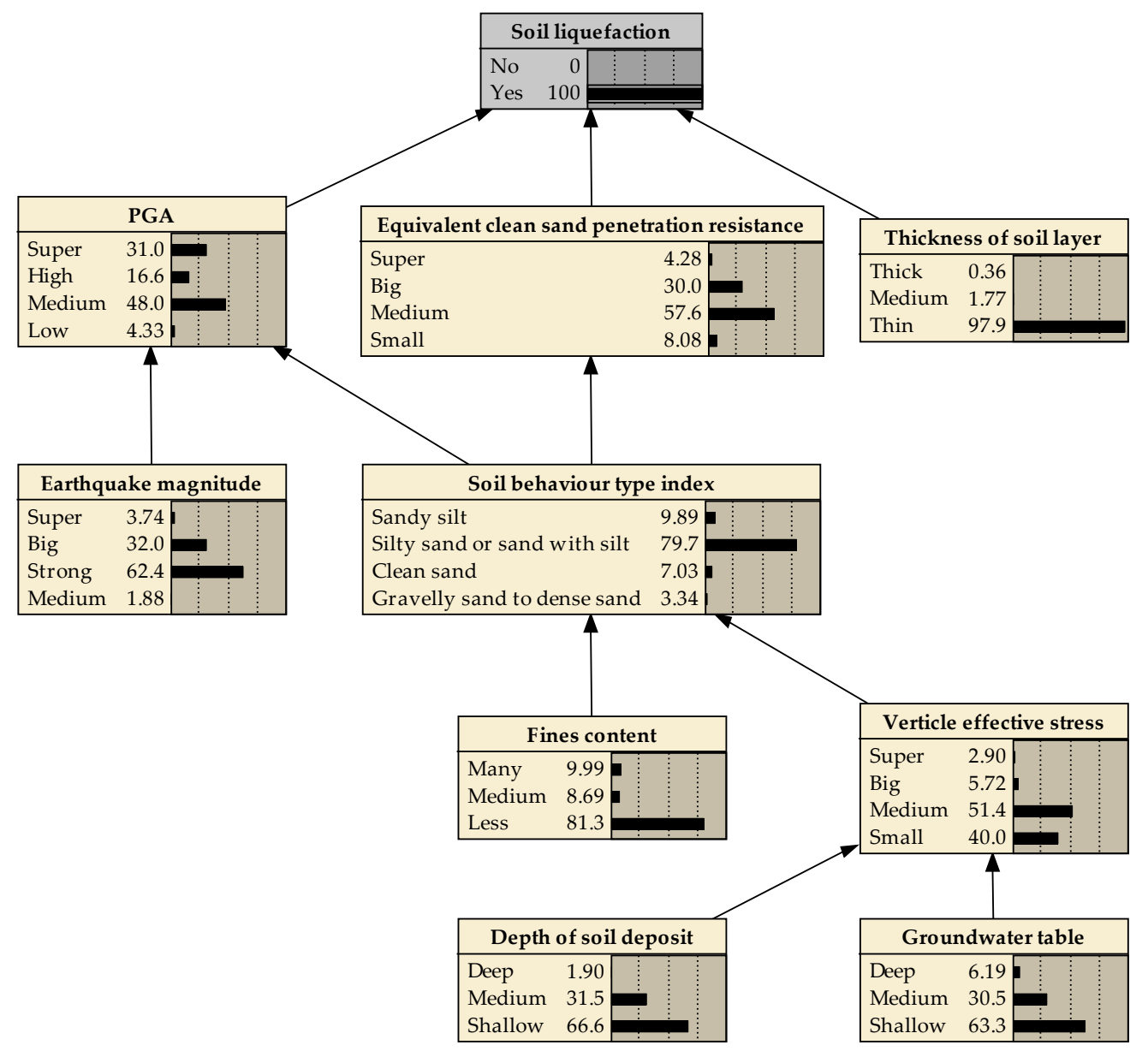

Figure 6. MPE of seismic soil liquefaction.

\subsection{Sensitivity Analysis}

Netica can effectively determine the extent to which any node's findings can affect the beliefs of another node, based on the findings that are currently entered. These findings may have mutual information (entropy reduction) or an expected reduction in the actual variance. In this study, to determine the impact of each factor on the liquefaction potential, a sensitivity analysis was performed on nine input factors with variance of beliefs. Based on the sensitivity analysis, a basic event that has a relatively large contribution to the probability of a resulting event makes it easier to reduce the probability of these basic events by considering effective measurements, thereby reducing the probability of a resulting event. The target node "soil liquefaction" is selected in Netica for sensitivity analysis, and the results are shown in Table 8. Table 8 presents that the mutual info of the "equivalent clean sand penetration resistance" node is the greatest, i.e., 0.13920 , which indicates that it has the strongest influence on "soil liquefaction," potential followed by "peak ground acceleration," "soil behaviour type index," and so on which have mutual info equal to 0.04439 and 0.03655 respectively, 
whereas the "depth of soil deposit" is bared minimum sensitive factor with a mutual info equal to 0.00004; those findings are strongly consistent with the literature.

Table 8. Sensitivity analysis of "soil liquefaction" node.

\begin{tabular}{llllllllll}
\hline Node & $\boldsymbol{q}_{c 1 N c s}$ & $\boldsymbol{a}_{\max }(\mathbf{g})$ & $\boldsymbol{I}_{c}$ & $\boldsymbol{T}_{\boldsymbol{s}}(\mathbf{m})$ & $\boldsymbol{\sigma}_{v}^{\prime}(\mathbf{k P a})$ & $\boldsymbol{F C}(\mathbf{\%})$ & $\boldsymbol{M}$ & $\boldsymbol{D}_{w}(\mathbf{m})$ & $\boldsymbol{D}_{s}(\mathbf{m})$ \\
\hline Mutual info & 0.13920 & 0.04439 & 0.03655 & 0.00334 & 0.00135 & 0.00021 & 0.00019 & 0.00009 & 0.00004 \\
Percent & 15.4000 & 4.9200 & 4.0500 & 0.3700 & 0.1490 & 0.0234 & 0.0212 & 0.0101 & 0.0047 \\
$\begin{array}{l}\text { Variance of } \\
\text { beliefs }\end{array}$ & 0.0423618 & 0.0133434 & 0.0117117 & 0.0010781 & 0.0004219 & 0.0000640 & 0.0000581 & 0.0000275 & 0.0000128 \\
\hline
\end{tabular}

\section{Conclusions and Future Prospect}

In this paper, probabilistic evaluation of CPT-based seismic soil liquefaction was carried by systematically integrating ISM and the BBN. The models were trained and tested based on Boulanger and Idriss database compiles from various soil liquefaction in different countries. The proposed model predicts the seismic soil liquefaction using major contributing factors on soil liquefaction. The most important conclusions of the present research work are as follows:

1. The accuracy of the proposed model is $78 \%$ and the F-score is 0.845 for liquefaction data and 0.621 for non-liquefaction data. In comparison with LR, SVM, RF, and NB models, the proposed model has better prediction ability and, because of a simple graphical result, its implementation is simpler.

2. The MPE of seismic soil liquefaction is that the peak ground acceleration = medium, equivalent clean sand penetration resistance $=$ medium, thickness of soil layer $=$ thin, earthquake magnitude $=$ strong, soil behaviour type index = silty sand, fines content $=$ less, vertical effective stress $=$ small, groundwater table $=$ shallow, and depth of soil deposit = shallow, which suits well in accordance with engineering practice.

3. Sensitivity analysis shows the most important parameters on the soil liquefaction: $q_{c 1 N c s}$ and $P G A$ determine the strongest, followed by $I_{c}, T_{s}, \sigma^{\prime} v, F C, M$, $D_{w}$, and $D_{s}$. It is probably due to the fact that the variation of these parameters is not very much.

Since the CPT case histories database have class imbalanced and the sampling biased in training and testing data set may lead anecdotal results to some degree. Nevertheless, these anecdotal findings regarding seismic soil liquefaction potential evaluation are greatly insightful from a preliminary viewpoint. In addition, owing to the ISM shortcomings, such as ignoring relationships between the nodes of the skipping-level, and there is no feedback circuit between any two levels, some significant node relationships will be ignored. In the future, the causal mapping approach should be employed to change the structure and to refine the prediction performance results, taking into account the ISM shortcomings. 


\section{Acknowledgments}

The authors would like to thank the experts who participated in the modeling process. The research described in this paper was part of research sponsored by the National Key Research \& Development Plan of China (Grant Nos. 2018YFC1505305 and 2016YFE0200100) and Key Program of National Natural Science Foundation of China (Grant No. 51639002). 
Table A. Seismic soil liquefaction database (Boulanger and Idriss 2014).

\begin{tabular}{|c|c|c|c|c|c|c|c|c|c|c|}
\hline Earthquake & $D_{s}(\mathrm{~m})$ & $D_{w}(\mathbf{m})$ & FC (\%) & $M$ & $a_{\max }(\mathrm{g})$ & Ts (m) & $\sigma_{v}^{\prime}(\mathbf{k P a})$ & $I_{c}$ & $q_{c 1 N c s}$ & Liq.? \\
\hline Borak Peak, 1983 & 3.4 & 2.4 & 30 & 6.88 & 0.5 & 1.9 & 51 & 2.24 & 146.8 & Yes \\
\hline Borak Peak, 1983 & 2.8 & 1.6 & 2 & 6.88 & 0.3 & 2.5 & 38 & 2.08 & 83 & Yes \\
\hline Borak Peak, 1983 & 2.4 & 0.8 & 20 & 6.88 & 0.5 & 1.6 & 29 & 2.07 & 133.2 & Yes \\
\hline Borak Peak, 1983 & 7.3 & 6.8 & 20 & 6.88 & 0.5 & 1 & 124 & 2.3 & 107.8 & Yes \\
\hline Chi-Chi, 1999 & 5.5 & 3.5 & 61 & 7.62 & 0.25 & 3 & 79 & 2.47 & 78.3 & Yes \\
\hline Chi-Chi, 1999 & 2.5 & 1 & 38 & 7.62 & 0.38 & 1 & 31 & 2.28 & 82.8 & Yes \\
\hline Chi-Chi, 1999 & 6 & 0.7 & 32 & 7.62 & 0.25 & 3 & 61 & 2.11 & 90.4 & Yes \\
\hline Chi-Chi, 1999 & 6.5 & 1.2 & 30 & 7.62 & 0.25 & 2.6 & 69 & 2.09 & 90.9 & Yes \\
\hline Chi-Chi, 1999 & 7 & 1 & 65 & 7.62 & 0.38 & 4 & 72 & 2.52 & 91.4 & Yes \\
\hline Chi-Chi, 1999 & 4.5 & 0.7 & 45 & 7.62 & 0.25 & 3 & 46 & 2.27 & 99.6 & Yes \\
\hline Chi-Chi, 1999 & 3 & 1.1 & 35 & 7.62 & 0.6 & 2 & 36 & 2.16 & 100.1 & Yes \\
\hline Chi-Chi, 1999 & 3.5 & 1 & 60 & 7.62 & 0.38 & 2 & 40 & 2.46 & 72.5 & Yes \\
\hline Chi-Chi, 1999 & 5 & 0.6 & 54 & 7.62 & 0.25 & 1 & 50 & 2.39 & 84.2 & Yes \\
\hline Chi-Chi, 1999 & 3.5 & 1.1 & 27 & 7.62 & 0.25 & 1.4 & 41 & 2.05 & 84.5 & Yes \\
\hline Chi-Chi, 1999 & 4.5 & 1.2 & 14 & 7.62 & 0.6 & 1 & 51 & 2.35 & 68.6 & Yes \\
\hline Christchurch, 2011 & 3.6 & 2 & 9 & 6.2 & 0.351 & 2.75 & 50 & 1.9 & 83.5 & Yes \\
\hline Christchurch, 2011 & 1.7 & 1.4 & 39 & 6.2 & 0.453 & 0.6 & 27 & 2.13 & 89.8 & Yes \\
\hline Christchurch, 2011 & 2 & 1.3 & 20 & 6.2 & 0.186 & 1.35 & 29 & 2.07 & 70.1 & Yes \\
\hline Christchurch, 2011 & 3.6 & 2 & 8 & 6.2 & 0.183 & 0.95 & 50 & 1.96 & 60.6 & Yes \\
\hline Christchurch, 2011 & 2.4 & 2 & 16 & 6.2 & 0.451 & 0.85 & 38 & 1.98 & 100.3 & Yes \\
\hline Christchurch, 2011 & 2.6 & 2 & 18 & 6.2 & 0.45 & 1.25 & 40 & 2.03 & 94.5 & Yes \\
\hline Christchurch, 2011 & 2.6 & 1.4 & 5 & 6.2 & 0.182 & 1.15 & 35 & 1.79 & 71 & Yes \\
\hline Christchurch, 2011 & 8.6 & 2.4 & 11 & 6.2 & 0.346 & 3.2 & 101 & 1.95 & 70.4 & Yes \\
\hline
\end{tabular}




\begin{tabular}{|c|c|c|c|c|c|c|c|c|c|c|}
\hline Earthquake & $D_{s}(\mathrm{~m})$ & $D_{w}(\mathrm{~m})$ & FC (\%) & $M$ & $a_{\max }(\mathrm{g})$ & Ts (m) & $\sigma_{v}^{\prime}(\mathbf{k P a})$ & $I_{c}$ & $\boldsymbol{q}_{c 1 N c s}$ & Liq.? \\
\hline Christchurch, 2011 & 2.8 & 1 & 11 & 6.2 & 0.447 & 1.1 & 34 & 1.9 & 116.6 & Yes \\
\hline Christchurch, 2011 & 2.6 & 1.2 & 10 & 6.2 & 0.186 & 1.1 & 34 & 1.92 & 73.6 & Yes \\
\hline Christchurch, 2011 & 5.5 & 1.4 & 0 & 6.2 & 0.46 & 2 & 64 & 1.62 & 146.3 & Yes \\
\hline Christchurch, 2011 & 2 & 1.5 & 22 & 6.2 & 0.181 & 0.9 & 30 & 2.05 & 75.1 & Yes \\
\hline Christchurch, 2011 & 7.3 & 1.3 & 4 & 6.2 & 0.323 & 3 & 80 & 1.85 & 83.8 & Yes \\
\hline Christchurch, 2011 & 5.8 & 2 & 12 & 6.2 & 0.354 & 1.9 & 70 & 1.96 & 71.5 & Yes \\
\hline Christchurch, 2011 & 4.3 & 1.6 & 6 & 6.2 & 0.172 & 1.5 & 53 & 1.83 & 67.4 & Yes \\
\hline Christchurch, 2011 & 3.7 & 1.7 & 7 & 6.2 & 0.396 & 1.6 & 48 & 1.8 & 101.2 & Yes \\
\hline Christchurch, 2011 & 3.8 & 1.8 & 24 & 6.2 & 0.382 & 0.3 & 48 & 2.15 & 78.7 & Yes \\
\hline Christchurch, 2011 & 2.3 & 1.9 & 8 & 6.2 & 0.177 & 0.85 & 36 & 1.87 & 62 & Yes \\
\hline Christchurch, 2011 & 4.5 & 2.3 & 7 & 6.2 & 0.339 & 2 & 60 & 2.01 & 35.3 & Yes \\
\hline Christchurch, 2011 & 6.1 & 1.4 & 26 & 6.2 & 0.455 & 4.25 & 70 & 2.11 & 104.1 & Yes \\
\hline Christchurch, 2011 & 4.8 & 2 & 4 & 6.2 & 0.347 & 1.1 & 61 & 1.87 & 51.1 & Yes \\
\hline Christchurch, 2011 & 5.2 & 1 & 3 & 6.2 & 0.188 & 2.95 & 58 & 1.65 & 107.5 & No \\
\hline Christchurch, 2011 & 3.7 & 0.8 & 2 & 6.2 & 0.187 & 2.65 & 42 & 1.68 & 117.1 & No \\
\hline Christchurch, 2011 & 4.8 & 0.5 & 0 & 6.2 & 0.186 & 1 & 50 & 1.69 & 127.3 & No \\
\hline Christchurch, 2011 & 1.9 & 0.9 & 9 & 6.2 & 0.186 & 1.2 & 25 & 1.86 & 53.9 & No \\
\hline Darfield, 2010 & 3.8 & 1.8 & 24 & 7 & 0.199 & 0.3 & 48 & 2.15 & 78.7 & Yes \\
\hline Darfield, 2010 & 4.3 & 1.6 & 6 & 7 & 0.211 & 1.5 & 53 & 1.83 & 67.4 & Yes \\
\hline Darfield, 2010 & 2.6 & 1.4 & 5 & 7 & 0.231 & 1.15 & 35 & 1.79 & 71 & Yes \\
\hline Darfield, 2010 & 2 & 1.3 & 20 & 7 & 0.204 & 1.35 & 29 & 2.07 & 70.1 & Yes \\
\hline Darfield, 2010 & 3.7 & 0.8 & 2 & 7 & 0.234 & 2.65 & 42 & 1.68 & 117.1 & Yes \\
\hline Darfield, 2010 & 2.6 & 1.2 & 10 & 7 & 0.211 & 1.1 & 34 & 1.92 & 73.6 & Yes \\
\hline Darfield, 2010 & 3.6 & 2 & 9 & 7 & 0.17 & 2.75 & 50 & 1.9 & 83.5 & Yes \\
\hline Darfield, 2010 & 1.7 & 1.4 & 39 & 7 & 0.219 & 0.6 & 27 & 2.13 & 89.8 & Yes \\
\hline Darfield, 2010 & 7.3 & 1.3 & 4 & 7 & 0.167 & 3 & 80 & 1.85 & 83.8 & Yes \\
\hline Darfield, 2010 & 5.2 & 1 & 3 & 7 & 0.237 & 2.95 & 58 & 1.65 & 107.5 & Yes \\
\hline
\end{tabular}




\begin{tabular}{|c|c|c|c|c|c|c|c|c|c|c|}
\hline Earthquake & $D_{s}(\mathrm{~m})$ & $D_{w}(\mathrm{~m})$ & FC (\%) & $M$ & $a_{\max }(\mathrm{g})$ & Ts (m) & $\sigma_{v}^{\prime}(\mathrm{kPa})$ & $I_{c}$ & $\boldsymbol{q}_{c 1 N c s}$ & Liq.? \\
\hline Darfield, 2010 & 6.1 & 1.4 & 26 & 7 & 0.217 & 4.25 & 70 & 2.11 & 104.1 & Yes \\
\hline Darfield, 2010 & 4.8 & 0.5 & 0 & 7 & 0.216 & 1 & 50 & 1.69 & 127.3 & Yes \\
\hline Darfield, 2010 & 5.8 & 2 & 12 & 7 & 0.17 & 1.9 & 70 & 1.96 & 71.5 & Yes \\
\hline Darfield, 2010 & 3.6 & 2 & 8 & 7 & 0.227 & 0.95 & 50 & 1.96 & 60.6 & Yes \\
\hline Darfield, 2010 & 6.5 & 1.5 & 3 & 7 & 0.231 & 3.1 & 74 & 1.74 & 92.6 & Yes \\
\hline Darfield, 2010 & 2.3 & 1.9 & 8 & 7 & 0.224 & 0.85 & 36 & 1.87 & 62 & Yes \\
\hline Darfield, 2010 & 1.9 & 0.9 & 9 & 7 & 0.239 & 1.2 & 25 & 1.86 & 53.9 & Yes \\
\hline Darfield, 2010 & 8.6 & 2.4 & 11 & 7 & 0.168 & 3.2 & 101 & 1.95 & 70.4 & Yes \\
\hline Darfield, 2010 & 5.5 & 1.4 & 0 & 7 & 0.219 & 2 & 64 & 1.62 & 146.3 & No \\
\hline Darfield, 2010 & 2.6 & 2 & 18 & 7 & 0.215 & 1.25 & 40 & 2.03 & 94.5 & No \\
\hline Darfield, 2010 & 2.4 & 2 & 16 & 7 & 0.214 & 0.85 & 38 & 1.98 & 100.3 & No \\
\hline Darfield, 2010 & 2.8 & 1 & 11 & 7 & 0.21 & 1.1 & 34 & 1.9 & 116.6 & No \\
\hline Darfield, 2010 & 4.8 & 2 & 4 & 7 & 0.187 & 1.1 & 61 & 1.87 & 51.1 & No \\
\hline Darfield, 2010 & 3.7 & 1.7 & 7 & 7 & 0.183 & 1.6 & 48 & 1.8 & 101.2 & No \\
\hline Darfield, 2010 & 4.5 & 2.3 & 7 & 7 & 0.183 & 2 & 60 & 2.01 & 35.3 & No \\
\hline Edgecumbe, 1987 & 4.1 & 2.4 & 10 & 6.6 & 0.27 & 1 & 57 & 1.85 & 66.6 & Yes \\
\hline Edgecumbe, 1987 & 5.5 & 1.2 & 1 & 6.6 & 0.27 & 1.4 & 60 & 1.75 & 79.9 & Yes \\
\hline Edgecumbe, 1987 & 7.8 & 1.6 & 5 & 6.6 & 0.42 & 1.5 & 84 & 1.76 & 83 & Yes \\
\hline Edgecumbe, 1987 & 1.9 & 0.6 & 5 & 6.6 & 0.44 & 1.8 & 22 & 1.62 & 61.5 & Yes \\
\hline Edgecumbe, 1987 & 5.1 & 1.2 & 1 & 6.6 & 0.28 & 3.4 & 54 & 1.82 & 83.9 & Yes \\
\hline Edgecumbe, 1987 & 5.5 & 2.5 & 5 & 6.6 & 0.39 & 0.9 & 71 & 1.82 & 73 & Yes \\
\hline Edgecumbe, 1987 & 8 & 2.5 & 5 & 6.6 & 0.31 & 3 & 94 & 1.76 & 75.1 & Yes \\
\hline Edgecumbe, 1987 & 3.8 & 0.8 & 5 & 6.6 & 0.44 & 3.5 & 41 & 1.88 & 61.3 & Yes \\
\hline Edgecumbe, 1987 & 2.8 & 1.2 & 35 & 6.6 & 0.37 & 1 & 35 & 1.9 & 162.6 & Yes \\
\hline Edgecumbe, 1987 & 7.2 & 1.7 & 30 & 6.6 & 0.4 & 1.6 & 79 & 2.41 & 67.3 & Yes \\
\hline Edgecumbe, 1987 & 2.7 & 0.5 & 1 & 6.6 & 0.43 & 3 & 29 & 1.97 & 56.8 & Yes \\
\hline Edgecumbe, 1987 & 5 & 1.3 & 5 & 6.6 & 0.26 & 6.2 & 56 & 1.89 & 57.1 & Yes \\
\hline
\end{tabular}




\begin{tabular}{|c|c|c|c|c|c|c|c|c|c|c|}
\hline Earthquake & $D_{s}(\mathrm{~m})$ & $D_{w}(\mathrm{~m})$ & FC (\%) & $M$ & $a_{\max }(\mathrm{g})$ & Ts (m) & $\sigma_{v}^{\prime}(\mathbf{k P a})$ & $I_{c}$ & $q_{c 1 N c s}$ & Liq.? \\
\hline Edgecumbe, 1987 & 5.9 & 2.1 & 5 & 6.6 & 0.41 & 1.4 & 72 & 1.67 & 94.6 & No \\
\hline Edgecumbe, 1987 & 4.2 & 1.5 & 15 & 6.6 & 0.4 & 0.6 & 51 & 1.67 & 125.4 & No \\
\hline Edgecumbe, 1987 & 1.9 & 0.9 & 1 & 6.6 & 0.37 & 0.5 & 25 & 1.41 & 156.4 & No \\
\hline Edgecumbe, 1987 & 4.4 & 1.4 & 5 & 6.6 & 0.27 & 1.8 & 51 & 2.23 & 47 & No \\
\hline Edgecumbe, 1987 & 4.7 & 4.4 & 5 & 6.6 & 0.26 & 0.6 & 80 & 1.58 & 149.9 & No \\
\hline Haichang, 1975 & 3.5 & 1 & 60 & 7 & 0.3 & 1 & 40 & 2.31 & 96.8 & No \\
\hline Hyogoken-Nambu, 1995 & 2.8 & 1.9 & 0 & 6.9 & 0.6 & 0.8 & 41 & 1.59 & 156.8 & No \\
\hline Hyogoken-Nambu, 1995 & 11.8 & 3.1 & 13 & 6.9 & 0.65 & 1.5 & 125 & 1.87 & 186.2 & No \\
\hline Hyogoken-Nambu, 1995 & 3.8 & 2 & 0 & 6.9 & 0.65 & 1.3 & 51 & 1.64 & 165.1 & No \\
\hline Hyogoken-Nambu, 1995 & 1.4 & 1 & 0 & 6.9 & 0.65 & 0.7 & 21 & 1.48 & 134.3 & No \\
\hline Hyogoken-Nambu, 1995 & 3.4 & 3 & 13 & 6.9 & 0.5 & 0.8 & 58 & 1.88 & 178.6 & No \\
\hline Hyogoken-Nambu, 1995 & 4.1 & 3 & 31 & 6.9 & 0.5 & 0.6 & 62 & 2.1 & 216.3 & No \\
\hline Hyogoken-Nambu, 1995 & 5 & 2.5 & 0 & 6.9 & 0.7 & 2 & 68 & 1.59 & 163.5 & No \\
\hline Hyogoken-Nambu, 1995 & 3.7 & 1.6 & 30 & 6.9 & 0.45 & 1 & 47 & 2.09 & 81.1 & Yes \\
\hline Hyogoken-Nambu, 1995 & 5.5 & 1.5 & 36 & 6.9 & 0.4 & 3 & 62 & 2.17 & 79.5 & Yes \\
\hline Hyogoken-Nambu, 1995 & 4.5 & 2.5 & 7 & 6.9 & 0.6 & 2 & 61 & 1.79 & 82.3 & Yes \\
\hline Hyogoken-Nambu, 1995 & 4.8 & 2.1 & 28 & 6.9 & 0.45 & 1.5 & 60 & 2.06 & 99.8 & Yes \\
\hline Hyogoken-Nambu, 1995 & 5.5 & 2.4 & 28 & 6.9 & 0.6 & 1.3 & 69 & 2.06 & 91.6 & Yes \\
\hline Hyogoken-Nambu, 1995 & 3.5 & 2.6 & 48 & 6.9 & 0.45 & 0.6 & 53 & 2.32 & 86.3 & Yes \\
\hline Hyogoken-Nambu, 1995 & 4.3 & 2 & 0 & 6.9 & 0.65 & 0.5 & 55 & 1.65 & 116.7 & Yes \\
\hline Hyogoken-Nambu, 1995 & 6 & 2.6 & 70 & 6.9 & 0.45 & 2 & 76 & 2.59 & 80.9 & Yes \\
\hline Hyogoken-Nambu, 1995 & 3.8 & 2 & 20 & 6.9 & 0.5 & 2.5 & 50 & 1.96 & 97.4 & Yes \\
\hline Hyogoken-Nambu, 1995 & 4.5 & 1.8 & 25 & 6.9 & 0.6 & 3 & 57 & 2.02 & 107.8 & Yes \\
\hline Hyogoken-Nambu, 1995 & 7 & 2 & 2 & 6.9 & 0.37 & 2 & 76 & 1.74 & 87.3 & Yes \\
\hline Hyogoken-Nambu, 1995 & 4 & 2.5 & 15 & 6.9 & 0.6 & 2 & 57 & 1.91 & 72.8 & Yes \\
\hline Hyogoken-Nambu, 1995 & 4.6 & 1.4 & 0 & 6.9 & 0.6 & 1.2 & 54 & 1.4 & 131.1 & Yes \\
\hline Hyogoken-Nambu, 1995 & 5.5 & 2.4 & 26 & 6.9 & 0.6 & 1 & 69 & 2.04 & 99.7 & Yes \\
\hline
\end{tabular}




\begin{tabular}{|c|c|c|c|c|c|c|c|c|c|c|}
\hline Earthquake & $D_{s}(\mathrm{~m})$ & $D_{w}(\mathrm{~m})$ & FC (\%) & $M$ & $a_{\max }(\mathrm{g})$ & Ts (m) & $\sigma_{v}^{\prime}(\mathbf{k P a})$ & $I_{c}$ & $q_{c 1 N c s}$ & Liq.? \\
\hline Hyogoken-Nambu, 1995 & 6.5 & 1.8 & 41 & 6.9 & 0.6 & 5 & 75 & 2.23 & 76.7 & Yes \\
\hline Hyogoken-Nambu, 1995 & 5.2 & 2 & 31 & 6.9 & 0.5 & 2.2 & 64 & 2.1 & 82 & Yes \\
\hline Imperial Valley, 1979 & 3.2 & 1.5 & 20 & 6.53 & 0.51 & 3.2 & 41 & 2.1 & 82.7 & Yes \\
\hline Imperial Valley, 1979 & 3.5 & 2.1 & 64 & 6.53 & 0.2 & 1 & 49 & 2.41 & 76.6 & Yes \\
\hline Imperial Valley, 1979 & 2.4 & 2.1 & 18 & 6.53 & 0.2 & 0.6 & 39 & 1.92 & 128.9 & No \\
\hline Imperial Valley, 1979 & 3.9 & 2.7 & 85 & 6.53 & 0.13 & 2.6 & 57 & 2.55 & 90.1 & No \\
\hline Inangahua, 1968 & 1.4 & 1.4 & 16 & 7.2 & 0.3 & 0.6 & 24 & 2.36 & 31.5 & Yes \\
\hline Inangahua, 1968 & 2 & 3.1 & 18 & 7.2 & 0.6 & 1.2 & 50 & 2.23 & 54.7 & Yes \\
\hline Kocaeli, 1999 & 3.2 & 2.5 & 12 & 7.51 & 0.4 & 1 & 50 & 1.91 & 121.6 & No \\
\hline Kocaeli, 1999 & 1.8 & 1 & 16 & 7.51 & 0.37 & 1.2 & 25 & 2.44 & 40.5 & Yes \\
\hline Kocaeli, 1999 & 2.4 & 0.5 & 42 & 7.51 & 0.4 & 1.2 & 26 & 1.8 & 113.2 & Yes \\
\hline Kocaeli, 1999 & 3.7 & 0.4 & 35 & 7.51 & 0.4 & 0.7 & 37 & 2.13 & 97.7 & Yes \\
\hline Kocaeli, 1999 & 3.6 & 1 & 9 & 7.51 & 0.37 & 4.8 & 41 & 1.77 & 91 & Yes \\
\hline Kocaeli, 1999 & 2.2 & 1.5 & 65 & 7.51 & 0.4 & 0.7 & 32 & 2.36 & 77.2 & Yes \\
\hline Kocaeli, 1999 & 4.9 & 0.8 & 11 & 7.51 & 0.3 & 3 & 51 & 1.84 & 85.1 & Yes \\
\hline Kocaeli, 1999 & 2.5 & 1.7 & 15 & 7.51 & 0.4 & 1 & 37 & 2.1 & 62.5 & Yes \\
\hline Kocaeli, 1999 & 1.6 & 0.5 & 5 & 7.51 & 0.37 & 1.6 & 19 & 2.32 & 16.1 & Yes \\
\hline Kocaeli, 1999 & 2.5 & 0.6 & 82 & 7.51 & 0.4 & 2 & 28 & 2.34 & 85.4 & Yes \\
\hline Kocaeli, 1999 & 2.2 & 1.7 & 12 & 7.51 & 0.4 & 0.9 & 34 & 1.84 & 129.6 & Yes \\
\hline Kocaeli, 1999 & 3.8 & 3.3 & 35 & 7.51 & 0.4 & 1 & 63 & 1.84 & 132.5 & Yes \\
\hline Kocaeli, 1999 & 2.1 & 0.5 & 65 & 7.51 & 0.4 & 1.2 & 23 & 1.9 & 104.1 & Yes \\
\hline Kocaeli, 1999 & 2.3 & 0.5 & 2 & 7.51 & 0.4 & 1.5 & 25 & 2.05 & 34.1 & Yes \\
\hline Kocaeli, 1999 & 2.3 & 1 & 12 & 7.51 & 0.4 & 1 & 29 & 2.55 & 28.9 & Yes \\
\hline Loma Prieta, 1989 & 6.5 & 6.2 & 15 & 6.93 & 0.4 & 1.2 & 115 & 1.75 & 163.4 & No \\
\hline Loma Prieta, 1989 & 5.3 & 3.5 & 9 & 6.93 & 0.38 & 4 & 79 & 1.86 & 93.3 & No \\
\hline Loma Prieta, 1989 & 8.2 & 3 & 20 & 6.93 & 0.36 & 2.7 & 102 & 2.06 & 100.6 & No \\
\hline Loma Prieta, 1989 & 8 & 1.8 & 4 & 6.93 & 0.28 & 4 & 87 & 1.16 & 311.9 & No \\
\hline
\end{tabular}




\begin{tabular}{|c|c|c|c|c|c|c|c|c|c|c|}
\hline Earthquake & $D_{s}(\mathrm{~m})$ & $D_{w}(\mathrm{~m})$ & FC (\%) & $M$ & $a_{\max }(\mathrm{g})$ & $T s(\mathrm{~m})$ & $\sigma_{v}^{\prime}(\mathbf{k P a})$ & $I_{c}$ & $q_{c 1 N c s}$ & Liq.? \\
\hline Loma Prieta, 1989 & 7 & 1.8 & 1 & 6.93 & 0.28 & 2 & 78 & 1.34 & 206.3 & No \\
\hline Loma Prieta, 1989 & 6.5 & 1.7 & 1 & 6.93 & 0.28 & 1 & 73 & 1.23 & 202.5 & No \\
\hline Loma Prieta, 1989 & 3.5 & 1.8 & 1 & 6.93 & 0.28 & 0.6 & 47 & 1.18 & 200.2 & No \\
\hline Loma Prieta, 1989 & 3.9 & 3.4 & 1 & 6.93 & 0.28 & 1 & 63 & 1.33 & 191.3 & No \\
\hline Loma Prieta, 1989 & 3.8 & 3 & 4 & 6.93 & 0.24 & 1.5 & 59 & 1.77 & 80.8 & Yes \\
\hline Loma Prieta, 1989 & 5.8 & 4.9 & 27 & 6.93 & 0.36 & 3 & 97 & 2.1 & 75.9 & Yes \\
\hline Loma Prieta, 1989 & 6.3 & 3 & 3 & 6.93 & 0.28 & 1.5 & 84 & 1.89 & 61.6 & Yes \\
\hline Loma Prieta, 1989 & 4.7 & 3 & 10 & 6.93 & 0.28 & 0.6 & 67 & 2.04 & 58.9 & Yes \\
\hline Loma Prieta, 1989 & 3.5 & 2 & 4 & 6.93 & 0.28 & 1 & 48 & 1.37 & 164.5 & No \\
\hline Loma Prieta, 1989 & 8.3 & 1.4 & 30 & 6.93 & 0.28 & 0.6 & 87 & 2.35 & 91.2 & Yes \\
\hline Loma Prieta, 1989 & 6.7 & 4.9 & 13 & 6.93 & 0.36 & 2.5 & 100 & 1.83 & 94.1 & Yes \\
\hline Loma Prieta, 1989 & 2 & 1.7 & 4 & 6.93 & 0.28 & 1 & 32 & 1.41 & 161.7 & No \\
\hline Loma Prieta, 1989 & 7.3 & 3 & 5 & 6.93 & 0.21 & 1.6 & 93 & 1.79 & 89.1 & Yes \\
\hline Loma Prieta, 1989 & 4.1 & 2.6 & 1 & 6.93 & 0.28 & 0.6 & 59 & 1.35 & 160.6 & No \\
\hline Loma Prieta, 1989 & 2.2 & 1 & 15 & 6.93 & 0.28 & 0.6 & 28 & 1.88 & 71.8 & Yes \\
\hline Loma Prieta, 1989 & 2.6 & 1.7 & 4 & 6.93 & 0.28 & 0.6 & 38 & 1.36 & 149.3 & No \\
\hline Loma Prieta, 1989 & 3.6 & 1.8 & 1 & 6.93 & 0.28 & 3.6 & 47 & 1.87 & 73.2 & Yes \\
\hline Loma Prieta, 1989 & 4.1 & 1.9 & 15 & 6.93 & 0.28 & 0.6 & 53 & 2.1 & 81 & Yes \\
\hline Loma Prieta, 1989 & 3.5 & 1.4 & 4 & 6.93 & 0.28 & 1 & 43 & 1.47 & 142.4 & No \\
\hline Loma Prieta, 1989 & 2.5 & 1.7 & 4 & 6.93 & 0.28 & 1 & 37 & 1.52 & 134.6 & No \\
\hline Loma Prieta, 1989 & 8.5 & 5.6 & 12 & 6.93 & 0.4 & 4 & 128 & 1.97 & 78.9 & Yes \\
\hline Loma Prieta, 1989 & 3.1 & 1.9 & 4 & 6.93 & 0.28 & 3 & 44 & 1.38 & 126.8 & No \\
\hline Loma Prieta, 1989 & 6.3 & 3 & 8 & 6.93 & 0.28 & 2.5 & 84 & 1.95 & 60.7 & Yes \\
\hline Loma Prieta, 1989 & 2.9 & 1.9 & 11 & 6.93 & 0.22 & 2.6 & 43 & 2 & 50.2 & Yes \\
\hline Loma Prieta, 1989 & 2 & 1 & 5 & 6.93 & 0.28 & 0.6 & 26 & 1.88 & 52.8 & Yes \\
\hline Loma Prieta, 1989 & 7 & 5.3 & 13 & 6.93 & 0.33 & 3.6 & 112 & 2.11 & 62 & Yes \\
\hline Loma Prieta, 1989 & 2.9 & 1.3 & 3 & 6.93 & 0.28 & 0.6 & 37 & 1.65 & 86.7 & Yes \\
\hline
\end{tabular}




\begin{tabular}{|c|c|c|c|c|c|c|c|c|c|c|}
\hline Earthquake & $D_{s}(\mathrm{~m})$ & $D_{w}(\mathrm{~m})$ & FC $(\%)$ & $M$ & $a_{\max }(\mathrm{g})$ & Ts (m) & $\sigma_{v}^{\prime}(\mathbf{k P a})$ & $I_{c}$ & $\boldsymbol{q}_{c 1 N c s}$ & Liq.? \\
\hline Loma Prieta, 1989 & 5.5 & 2.8 & 3 & 6.93 & 0.28 & 0.6 & 73 & 2.21 & 24.4 & Yes \\
\hline Loma Prieta, 1989 & 4.7 & 3.7 & 1 & 6.93 & 0.28 & 0.6 & 73 & 1.57 & 107.7 & No \\
\hline Loma Prieta, 1989 & 4.2 & 2.7 & 10 & 6.93 & 0.28 & 0.6 & 60 & 1.9 & 72.5 & Yes \\
\hline Loma Prieta, 1989 & 5.2 & 3.5 & 18 & 6.93 & 0.38 & 3.5 & 79 & 1.97 & 91.4 & Yes \\
\hline Loma Prieta, 1989 & 5 & 1.5 & 20 & 6.93 & 0.16 & 4 & 59 & 2.06 & 84.2 & Yes \\
\hline Loma Prieta, 1989 & 6 & 4.9 & 25 & 6.93 & 0.36 & 3.7 & 99 & 2.03 & 87 & Yes \\
\hline Loma Prieta, 1989 & 3.3 & 2.5 & 1 & 6.93 & 0.28 & 2.7 & 50 & 1.56 & 123.5 & Yes \\
\hline Loma Prieta, 1989 & 4 & 2.4 & 15 & 6.93 & 0.26 & 3.1 & 58 & 2.09 & 74 & No \\
\hline Loma Prieta, 1989 & 2.9 & 1.8 & 42 & 6.93 & 0.26 & 2.7 & 43 & 2.23 & 85.7 & No \\
\hline Loma Prieta, 1989 & 2.6 & 2.4 & 5 & 6.93 & 0.26 & 1.2 & 45 & 2.15 & 35.8 & Yes \\
\hline Loma Prieta, 1989 & 5 & 1.8 & 4 & 6.93 & 0.28 & 0.6 & 60 & 1.57 & 114.8 & Yes \\
\hline Loma Prieta, 1989 & 6.2 & 5.5 & 10 & 6.93 & 0.24 & 1.3 & 102 & 2.22 & 112.7 & No \\
\hline Loma Prieta, 1989 & 4.5 & 3.4 & 4 & 6.93 & 0.22 & 2.1 & 72 & 1.77 & 93.3 & Yes \\
\hline Loma Prieta, 1989 & 1.4 & 1.4 & 4 & 6.93 & 0.28 & 0.6 & 24 & 1.86 & 51 & Yes \\
\hline Loma Prieta, 1989 & 6 & 2.1 & 10 & 6.93 & 0.21 & 4.2 & 73 & 2.02 & 57.5 & Yes \\
\hline Loma Prieta, 1989 & 8.7 & 5 & 13 & 6.93 & 0.13 & 1.4 & 124 & 2.18 & 47.9 & Yes \\
\hline Loma Prieta, 1989 & 7.4 & 4.8 & 4 & 6.93 & 0.36 & 4.5 & 111 & 1.72 & 106.1 & Yes \\
\hline Loma Prieta, 1989 & 2.8 & 2.4 & 23 & 6.93 & 0.26 & 1.6 & 47 & 2.4 & 60.3 & Yes \\
\hline Loma Prieta, 1989 & 11 & 2.4 & 30 & 6.93 & 0.28 & 0.6 & 120 & 2.24 & 85.9 & Yes \\
\hline Loma Prieta, 1989 & 2.7 & 1.5 & 15 & 6.93 & 0.47 & 1 & 38 & 2.07 & 99.5 & Yes \\
\hline Loma Prieta, 1989 & 2.5 & 1.8 & 2 & 6.93 & 0.28 & 1 & 38 & 1.52 & 121 & Yes \\
\hline Loma Prieta, 1989 & 4.7 & 1.8 & 10 & 6.93 & 0.22 & 2 & 59 & 1.94 & 68.2 & Yes \\
\hline Loma Prieta, 1989 & 4.4 & 1.5 & 3 & 6.93 & 0.28 & 0.6 & 52 & 1.57 & 112.1 & Yes \\
\hline Loma Prieta, 1989 & 6 & 4.1 & 18 & 6.93 & 0.38 & 2.6 & 91 & 2.06 & 79.2 & Yes \\
\hline Loma Prieta, 1989 & 4.3 & 2.1 & 9 & 6.93 & 0.22 & 4.4 & 58 & 1.88 & 75 & Yes \\
\hline Loma Prieta, 1989 & 2.9 & 1.2 & 5 & 6.93 & 0.28 & 0.6 & 36 & 1.59 & 108.3 & Yes \\
\hline Loma Prieta, 1989 & 5.5 & 3.5 & 52 & 6.93 & 0.18 & 3.5 & 70 & 2.35 & 76.3 & Yes \\
\hline
\end{tabular}




\begin{tabular}{|c|c|c|c|c|c|c|c|c|c|c|}
\hline Earthquake & $D_{s}(\mathrm{~m})$ & $D_{w}(\mathrm{~m})$ & FC (\%) & $M$ & $a_{\max }(\mathrm{g})$ & $T s(\mathrm{~m})$ & $\sigma_{v}^{\prime}(\mathbf{k P a})$ & $I_{c}$ & $q_{c 1 N c s}$ & Liq.? \\
\hline Loma Prieta, 1989 & 7.4 & 4.2 & 11 & 6.93 & 0.36 & 5 & 105 & 1.9 & 86.5 & Yes \\
\hline Loma Prieta, 1989 & 3.2 & 2.7 & 12 & 6.93 & 0.22 & 0.7 & 53 & 1.85 & 95.8 & No \\
\hline Loma Prieta, 1989 & 3.6 & 1.2 & 3 & 6.93 & 0.28 & 0.6 & 43 & 1.4 & 116.6 & Yes \\
\hline Loma Prieta, 1989 & 4.9 & 2.5 & 12 & 6.93 & 0.22 & 5 & 67 & 2.08 & 54.8 & No \\
\hline Loma Prieta, 1989 & 7.5 & 3 & 12 & 6.93 & 0.28 & 3 & 95 & 1.78 & 96.4 & Yes \\
\hline Loma Prieta, 1989 & 8.6 & 1.3 & 30 & 6.93 & 0.28 & 0.6 & 89 & 2.27 & 90.6 & Yes \\
\hline Loma Prieta, 1989 & 4.1 & 1.9 & 15 & 6.93 & 0.28 & 0.6 & 53 & 1.94 & 106.7 & Yes \\
\hline Loma Prieta, 1989 & 3.5 & 0.8 & 24 & 6.93 & 0.22 & 4 & 39 & 2.09 & 78.4 & Yes \\
\hline Loma Prieta, 1989 & 7.5 & 5 & 18 & 6.93 & 0.34 & 1 & 113 & 2.14 & 66.2 & Yes \\
\hline Loma Prieta, 1989 & 9.8 & 2.2 & 27 & 6.93 & 0.28 & 0.6 & 107 & 2.37 & 76.1 & Yes \\
\hline Loma Prieta, 1989 & 2.1 & 1.5 & 4 & 6.93 & 0.28 & 0.6 & 31 & 1.9 & 42.5 & Yes \\
\hline Loma Prieta, 1989 & 8 & 4.8 & 7 & 6.93 & 0.36 & 5 & 116 & 1.79 & 89.1 & Yes \\
\hline Loma Prieta, 1989 & 4 & 1.7 & 10 & 6.93 & 0.13 & 4.8 & 52 & 2 & 65.9 & No \\
\hline Loma Prieta, 1989 & 4.5 & 1.8 & 14 & 6.93 & 0.13 & 2.3 & 57 & 2.06 & 66.6 & No \\
\hline Loma Prieta, 1989 & 5.3 & 4.2 & 30 & 6.93 & 0.13 & 2.2 & 86 & 2.09 & 85.1 & No \\
\hline Loma Prieta, 1989 & 7.2 & 6.4 & 9 & 6.93 & 0.12 & 1.6 & 123 & 2.28 & 53.8 & No \\
\hline Loma Prieta, 1989 & 6.9 & 6.4 & 7 & 6.93 & 0.12 & 1 & 120 & 2.5 & 36.7 & No \\
\hline Nihonkai-Chubu, 1983 & 2.9 & 2.4 & 5 & 7.7 & 0.17 & 1 & 47 & 2.1 & 62 & No \\
\hline Nihonkai-Chubu, 1983 & 1.8 & 0.8 & 5 & 7.7 & 0.17 & 2 & 23 & 2.22 & 37.5 & Yes \\
\hline Nihonkai-Chubu, 1983 & 4.5 & 1 & 5 & 7.7 & 0.17 & 2.2 & 49 & 2.29 & 34.9 & Yes \\
\hline Niigata, 1964 & 5.5 & 1.7 & 5 & 7.6 & 0.162 & 1 & 61 & 1.84 & 152.1 & No \\
\hline Niigata, 1964 & 3.1 & 1.4 & 5 & 7.6 & 0.162 & 3 & 40 & 2.18 & 51.1 & Yes \\
\hline Niigata, 1964 & 4.4 & 1.1 & 3 & 7.6 & 0.162 & 3 & 49 & 2.11 & 61.2 & Yes \\
\hline Northridge, 1994 & 8.9 & 7.2 & 50 & 6.69 & 0.84 & 1.5 & 147 & 2.33 & 127.5 & Yes \\
\hline Northridge, 1994 & 3.9 & 3.4 & 20 & 6.69 & 0.8 & 1 & 66 & 1.97 & 132.5 & Yes \\
\hline Superstition Hills 01, 1987 & 4.8 & 1.2 & 30 & 6.22 & 0.133 & 4.4 & 54 & 2.13 & 120.6 & No \\
\hline Superstition Hills 01, 1987 & 3.5 & 2.1 & 64 & 6.22 & 0.09 & 1 & 49 & 2.41 & 76.6 & No \\
\hline
\end{tabular}




\begin{tabular}{|c|c|c|c|c|c|c|c|c|c|c|}
\hline Earthquake & $D_{s}(\mathrm{~m})$ & $D_{w}(\mathrm{~m})$ & FC ( $(\%)$ & $M$ & $a_{\max }(\mathrm{g})$ & Ts $(\mathrm{m})$ & $\sigma_{v}^{\prime}(\mathbf{k P a})$ & $I_{c}$ & $q_{c 1 N c s}$ & Liq.? \\
\hline Superstition Hills 02, 1987 & 3.5 & 2.1 & 64 & 6.54 & 0.2 & 1 & 49 & 2.41 & 76.6 & No \\
\hline Superstition Hills 02, 1987 & 2.4 & 2.1 & 18 & 6.54 & 0.18 & 0.6 & 39 & 1.92 & 128.9 & No \\
\hline Superstition Hills 02, 1987 & 3.9 & 2.7 & 85 & 6.54 & 0.174 & 2.6 & 57 & 2.55 & 90.1 & No \\
\hline Superstition Hills 02, 1987 & 4.8 & 1.2 & 30 & 6.54 & 0.206 & 4.4 & 54 & 2.13 & 120.6 & Yes \\
\hline Tangshan, 1976 & 4.7 & 1.1 & 4 & 7.6 & 0.64 & 0.6 & 49 & 1.76 & 159.3 & No \\
\hline Tangshan, 1976 & 4.8 & 1.1 & 10 & 7.6 & 0.64 & 1.2 & 50 & 1.84 & 125 & No \\
\hline Tangshan, 1976 & 6.6 & 3.5 & 2 & 7.6 & 0.26 & 1.2 & 89 & 1.74 & 163.1 & No \\
\hline Tangshan, 1976 & 3.6 & 3.1 & 5 & 7.6 & 0.25 & 0.9 & 58 & 1.57 & 128.3 & No \\
\hline Tangshan, 1976 & 6.3 & 2.5 & 2 & 7.6 & 0.2 & 3.4 & 78 & 1.5 & 157.4 & No \\
\hline Tangshan, 1976 & 7.4 & 2.3 & 2 & 7.6 & 0.16 & 3.3 & 86 & 1.81 & 72.6 & No \\
\hline Tangshan, 1976 & 5.3 & 1.5 & 4 & 7.6 & 0.64 & 1.6 & 57 & 2.14 & 81.9 & Yes \\
\hline Tangshan, 1976 & 6.3 & 2.2 & 3 & 7.6 & 0.64 & 2.2 & 72 & 1.83 & 117.1 & Yes \\
\hline Tangshan, 1976 & 3.3 & 1.1 & 5 & 7.6 & 0.25 & 2.5 & 39 & 1.85 & 69.8 & Yes \\
\hline Tangshan, 1976 & 2 & 0.2 & 75 & 7.6 & 0.12 & 2 & 20 & 2.28 & 81.8 & Yes \\
\hline Tangshan, 1976 & 3.3 & 1 & 75 & 7.6 & 0.12 & 1 & 38 & 2.59 & 72.7 & Yes \\
\hline Tangshan, 1976 & 5.6 & 1.1 & 5 & 7.6 & 0.58 & 1.6 & 60 & 1.78 & 141.4 & Yes \\
\hline Tangshan, 1976 & 2.3 & 0.8 & 5 & 7.6 & 0.25 & 0.9 & 27 & 1.73 & 76.6 & Yes \\
\hline Tangshan, 1976 & 2 & 0.9 & 9 & 7.6 & 0.61 & 1.2 & 24 & 2.21 & 69.1 & Yes \\
\hline Tangshan, 1976 & 2.7 & 1.5 & 6 & 7.6 & 0.64 & 0.6 & 36 & 1.79 & 122.3 & Yes \\
\hline Tangshan, 1976 & 3.3 & 2.3 & 5 & 7.6 & 0.18 & 1.3 & 48 & 1.97 & 52.6 & Yes \\
\hline Tangshan, 1976 & 3.4 & 3 & 41 & 7.6 & 0.64 & 0.8 & 55 & 2.23 & 112.2 & Yes \\
\hline Tangshan, 1976 & 4 & 0.2 & 75 & 7.6 & 0.12 & 1 & 38 & 2.3 & 90.2 & Yes \\
\hline Tangshan, 1976 & 6.2 & 3.7 & 5 & 7.6 & 0.64 & 1.1 & 85 & 2.27 & 71 & Yes \\
\hline Tohoku, 2011 & 4.2 & 2.5 & 5 & 9 & 0.18 & 0.8 & 60 & 1.77 & 87.3 & No \\
\hline Tohoku, 2011 & 4.8 & 1.1 & 3 & 9 & 0.17 & 1.6 & 53 & 1.75 & 133.5 & No \\
\hline Tohoku, 2011 & 10.1 & 1.2 & 11 & 9 & 0.169 & 6.5 & 102 & 1.85 & 92.9 & No \\
\hline Tohoku, 2011 & 6.8 & 1.1 & 15 & 9 & 0.21 & 1 & 71 & 1.9 & 101.6 & Yes \\
\hline
\end{tabular}




\begin{tabular}{lcccccccccc}
\hline Earthquake & $\boldsymbol{D}_{\boldsymbol{s}}(\mathbf{m})$ & $\boldsymbol{D}_{w}(\mathbf{m})$ & $\mathbf{F C}(\mathbf{\%})$ & $\boldsymbol{M}$ & $\boldsymbol{a}_{\mathbf{m a x}}(\mathbf{g})$ & $\boldsymbol{T}_{\boldsymbol{s}}(\mathbf{m})$ & $\boldsymbol{\sigma}_{v}^{\prime}(\mathbf{k P a})$ & $\boldsymbol{I}_{c}$ & $\boldsymbol{q}_{c 1 N c s}$ & Liq.? \\
\hline Tohoku, 2011 & 9 & 1.3 & 2 & 9 & 0.22 & 1.2 & 93 & 1.74 & 99.1 & Yes \\
Tohoku, 2011 & 6.3 & 1.6 & 66 & 9 & 0.256 & 1.6 & 71 & 2.53 & 81.1 & Yes \\
Tohoku, 2011 & 2.8 & 1.2 & 25 & 9 & 0.199 & 1.6 & 36 & 2.03 & 98 & Yes \\
Vectoria (Mexicali), 1980 & 2.7 & 2.2 & 8 & 6.33 & 0.19 & 1 & 43 & 1.81 & 54.9 & Yes \\
Vectoria (Mexicali), 1980 & 2.3 & 2 & 32 & 6.33 & 0.19 & 0.6 & 38 & 2.11 & 96.7 & Yes \\
Vectoria (Mexicali), 1980 & 2.9 & 2 & 51 & 6.33 & 0.19 & 1.8 & 43 & 2.35 & 80.6 & Yes \\
Vectoria (Mexicali), 1980 & 3 & 2.2 & 52 & 6.33 & 0.19 & 3.2 & 46 & 2.37 & 83.5 & Yes \\
Westmorland,1981 & 2.4 & 2.1 & 18 & 5.9 & 0.2 & 0.6 & 39 & 1.92 & 128.9 & No \\
Westmorland,1981 & 3.9 & 2.7 & 85 & 5.9 & 0.32 & 2.6 & 57 & 2.55 & 90.1 & Yes \\
Westmorland,1981 & 3.2 & 1.5 & 20 & 5.9 & 0.09 & 3.2 & 41 & 2.1 & 82.7 & No \\
Westmorland,1981 & 3.5 & 2.1 & 64 & 5.9 & 0.2 & 1 & 49 & 2.41 & 76.6 & Yes \\
Westmorland,1981 & 4.8 & 1.2 & 30 & 5.9 & 0.26 & 4.4 & 54 & 2.13 & 120.6 & Yes \\
\hline
\end{tabular}




\section{Appendix B}

Table B1. Initial reachability matrix.

\begin{tabular}{ccccccccccc}
\hline $\mathbf{V}_{\mathbf{i}}$ & $\mathbf{V}_{\mathbf{1}}$ & $\mathbf{V}_{\mathbf{2}}$ & $\mathbf{V}_{\mathbf{3}}$ & $\mathbf{V}_{\mathbf{4}}$ & $\mathbf{V}_{\mathbf{5}}$ & $\mathbf{V}_{\mathbf{6}}$ & $\mathbf{V}_{\mathbf{7}}$ & $\mathbf{V}_{\mathbf{8}}$ & $\mathbf{V}_{\mathbf{9}}$ & $\mathbf{V}_{\mathbf{1 0}}$ \\
\hline $\mathrm{V}_{\mathbf{1}}$ & 1 & 1 & 0 & 0 & 0 & 0 & 0 & 0 & 0 & 1 \\
$\mathrm{~V}_{2}$ & 0 & 1 & 0 & 0 & 0 & 0 & 0 & 0 & 0 & 1 \\
$\mathrm{~V}_{3}$ & 0 & 0 & 1 & 1 & 1 & 0 & 0 & 0 & 0 & 1 \\
$\mathrm{~V}_{4}$ & 0 & 0 & 0 & 1 & 0 & 0 & 0 & 0 & 0 & 1 \\
$\mathrm{~V}_{5}$ & 0 & 1 & 0 & 1 & 1 & 0 & 0 & 0 & 0 & 1 \\
$\mathrm{~V}_{6}$ & 0 & 0 & 0 & 1 & 1 & 1 & 0 & 0 & 0 & 1 \\
$\mathrm{~V}_{7}$ & 0 & 0 & 0 & 1 & 0 & 1 & 1 & 0 & 0 & 1 \\
$\mathrm{~V}_{8}$ & 0 & 0 & 0 & 1 & 0 & 1 & 0 & 1 & 0 & 1 \\
$\mathrm{~V}_{9}$ & 0 & 0 & 0 & 0 & 0 & 0 & 0 & 0 & 1 & 1 \\
$\mathrm{~F}_{10}$ & 0 & 0 & 0 & 0 & 0 & 0 & 0 & 0 & 0 & 1 \\
\hline
\end{tabular}

Table B2. Final reachability matrix.

\begin{tabular}{ccccccccccccc}
\hline $\mathbf{V}_{\mathbf{i}}$ & $\mathbf{V}_{\mathbf{1}}$ & $\mathbf{V}_{\mathbf{2}}$ & $\mathbf{V}_{\mathbf{3}}$ & $\mathbf{V}_{\mathbf{4}}$ & $\mathbf{V}_{\mathbf{5}}$ & $\mathbf{V}_{\mathbf{6}}$ & $\mathbf{V}_{\mathbf{7}}$ & $\mathbf{V}_{\mathbf{8}}$ & $\mathbf{V}_{\mathbf{9}}$ & $\mathbf{V}_{\mathbf{1 0}}$ & Dri. & Rank \\
\hline $\mathrm{V}_{1}$ & 1 & 1 & 0 & 0 & 0 & 0 & 0 & 0 & 0 & 1 & 3 & $\mathrm{III}$ \\
$\mathrm{V}_{2}$ & 0 & 1 & 0 & 0 & 0 & 0 & 0 & 0 & 0 & 1 & 2 & $\mathrm{IV}$ \\
$\mathrm{V}_{3}$ & 0 & $1^{*}$ & 1 & 1 & 1 & 0 & 0 & 0 & 0 & 1 & 5 & $\mathrm{I}$ \\
$\mathrm{V}_{4}$ & 0 & 0 & 0 & 1 & 0 & 0 & 0 & 0 & 0 & 1 & 2 & $\mathrm{IV}$ \\
$\mathrm{V}_{5}$ & 0 & 1 & 0 & 1 & 1 & 0 & 0 & 0 & 0 & 1 & 4 & $\mathrm{II}$ \\
$\mathrm{V}_{6}$ & 0 & $1^{*}$ & 0 & 1 & 1 & 1 & 0 & 0 & 0 & 1 & 5 & $\mathrm{I}$ \\
$\mathrm{V}_{7}$ & 0 & 0 & 0 & 1 & $1^{*}$ & 1 & 1 & 0 & 0 & 1 & 5 & $\mathrm{I}$ \\
$\mathrm{V}_{8}$ & 0 & 0 & 0 & 1 & $1^{*}$ & 1 & 0 & 1 & 0 & 1 & 5 & $\mathrm{I}$ \\
$\mathrm{V}_{9}$ & 0 & 0 & 0 & 0 & 0 & 0 & 0 & 0 & 1 & 1 & 2 & IV \\
$\mathrm{V}_{10}$ & 0 & 0 & 0 & 0 & 0 & 0 & 0 & 0 & 0 & 1 & 1 & V \\
Dep. & 1 & 5 & 1 & 6 & 5 & 3 & 1 & 1 & 1 & 10 & $34 / 34$ & \\
Rank & $\mathrm{V}$ & III & $\mathrm{V}$ & $\mathrm{II}$ & $\mathrm{III}$ & $\mathrm{IV}$ & $\mathrm{V}$ & $\mathrm{V}$ & $\mathrm{V}$ & $\mathrm{I}$ & & V/V \\
\hline
\end{tabular}

Dri.: driving power; Dep.: dependence power

Table B3. Level partition - Iteration 1

\begin{tabular}{|c|c|c|c|c|}
\hline $\mathbf{V}_{i}$ & $S_{r}$ & $S_{a}$ & $\mathbf{S}_{i}$ & $\mathbf{L}_{i}$ \\
\hline $\mathrm{V}_{1}$ & $\mathrm{~V}_{1}, \mathrm{~V}_{2}, \mathrm{~V}_{10}$ & $\mathrm{~V}_{1}$ & $\mathrm{~V}_{1}$ & \\
\hline $\mathrm{V}_{2}$ & $\mathrm{~V}_{2}, \mathrm{~V}_{10}$ & $\mathrm{~V}_{1}, \mathrm{~V}_{2}, \mathrm{~V}_{3}, \mathrm{~V}_{5}, \mathrm{~V}_{6}$ & $\mathrm{~V}_{2}$ & \\
\hline $\mathrm{V}_{3}$ & $\mathrm{~V}_{2}, \mathrm{~V}_{3}, \mathrm{~V}_{4}, \mathrm{~V}_{5}, \mathrm{~V}_{10}$ & $\mathrm{~V}_{3}$ & $\mathrm{~V}_{3}$ & \\
\hline $\mathrm{V}_{4}$ & $\mathrm{~V}_{4}, \mathrm{~V}_{10}$ & $\mathrm{~V}_{3}, \mathrm{~V}_{4}, \mathrm{~V}_{5}, \mathrm{~V}_{6}, \mathrm{~V}_{7}, \mathrm{~V}_{8}$ & $\mathrm{~V}_{4}$ & \\
\hline $\mathrm{V}_{5}$ & $\mathrm{~V}_{2}, \mathrm{~V}_{4}, \mathrm{~V}_{5}, \mathrm{~V}_{10}$ & $\mathrm{~V}_{3}, \mathrm{~V}_{5}, \mathrm{~V}_{6}, \mathrm{~V}_{7}, \mathrm{~V}_{8}$ & $\mathrm{~V}_{5}$ & \\
\hline $\mathrm{V}_{6}$ & $\mathrm{~V}_{2}, \mathrm{~V}_{4}, \mathrm{~V}_{5}, \mathrm{~V}_{6}, \mathrm{~V}_{10}$ & $\mathrm{~V}_{6}, \mathrm{~V}_{7}, \mathrm{~V}_{8}$ & $\mathrm{~V}_{6}$ & \\
\hline
\end{tabular}




\begin{tabular}{cllll}
\hline $\mathrm{V}_{i}$ & $S_{r}$ & $S_{a}$ & $\mathrm{~S}_{i}$ & $\mathrm{~L}_{i}$ \\
\hline $\mathrm{V}_{7}$ & $\mathrm{~V}_{4}, \mathrm{~V}_{5}, \mathrm{~V}_{6}, \mathrm{~V}_{7}, \mathrm{~V}_{10}$ & $\mathrm{~V}_{7}$ & $\mathrm{~V}_{7}$ & \\
$\mathrm{~V}_{8}$ & $\mathrm{~V}_{4}, \mathrm{~V}_{5}, \mathrm{~V}_{6}, \mathrm{~V}_{8}, \mathrm{~V}_{10}$ & $\mathrm{~V}_{8}$ & $\mathrm{~V}_{8}$ & \\
$\mathrm{~V}_{9}$ & $\mathrm{~V}_{9}, \mathrm{~V}_{10}$ & $\mathrm{~V}_{9}$ & $\mathrm{~V}_{9}$ & \\
$\mathrm{~V}_{10}$ & $\mathrm{~V}_{10}$ & $\mathrm{~V}_{1}, \mathrm{~V}_{2}, \mathrm{~V}_{3}, \mathrm{~V}_{4}, \mathrm{~V}_{5}, \mathrm{~V}_{6}, \mathrm{~V}_{7}, \mathrm{~V}_{8}, \mathrm{~V}_{9}, \mathrm{~V}_{10}$ & $\mathrm{~V}_{10}$ & $\mathrm{~L}_{10}$ \\
\hline
\end{tabular}

Table B4. Level partition - Iteration 2

\begin{tabular}{lllll}
\hline $\mathrm{V}_{i}$ & $\mathrm{~S}_{\boldsymbol{r}}$ & $\mathrm{S}_{a}$ & $\mathrm{~S}_{i}$ & $\mathrm{~L}_{i}$ \\
\hline $\mathrm{V}_{1}$ & $\mathrm{~V}_{1}, \mathrm{~V}_{2}$ & $\mathrm{~V}_{1}$ & $\mathrm{~V}_{1}$ & \\
$\mathrm{~V}_{2}$ & $\mathrm{~V}_{2}$ & $\mathrm{~V}_{1}, \mathrm{~V}_{2}, \mathrm{~V}_{3}, \mathrm{~V}_{5}, \mathrm{~V}_{6}$ & $\mathrm{~V}_{2}$ & $\mathrm{~L}_{2}$ \\
$\mathrm{~V}_{3}$ & $\mathrm{~V}_{2}, \mathrm{~V}_{3}, \mathrm{~V}_{4}, \mathrm{~V}_{5}$ & $\mathrm{~V}_{3}$ & $\mathrm{~V}_{3}$ & \\
$\mathrm{~V}_{4}$ & $\mathrm{~V}_{4}$ & $\mathrm{~V}_{3}, \mathrm{~V}_{4}, \mathrm{~V}_{5}, \mathrm{~V}_{6}, \mathrm{~V}_{7}, \mathrm{~V}_{8}$ & $\mathrm{~V}_{4}$ & $\mathrm{~L}_{2}$ \\
$\mathrm{~V}_{5}$ & $\mathrm{~V}_{2}, \mathrm{~V}_{4}, \mathrm{~V}_{5}$ & $\mathrm{~V}_{3}, \mathrm{~V}_{5}, \mathrm{~V}_{6}, \mathrm{~V}_{7}, \mathrm{~V}_{8}$ & $\mathrm{~V}_{5}$ & \\
$\mathrm{~V}_{6}$ & $\mathrm{~V}_{2}, \mathrm{~V}_{4}, \mathrm{~V}_{5}, \mathrm{~V}_{6}$ & $\mathrm{~V}_{6}, \mathrm{~V}_{7}, \mathrm{~V}_{8}$ & $\mathrm{~V}_{6}$ & \\
$\mathrm{~V}_{7}$ & $\mathrm{~V}_{4}, \mathrm{~V}_{5}, \mathrm{~V}_{6}, \mathrm{~V}_{7}$ & $\mathrm{~V}_{7}$ & $\mathrm{~V}_{7}$ & \\
$\mathrm{~V}_{8}$ & $\mathrm{~V}_{4}, \mathrm{~V}_{5}, \mathrm{~V}_{6}, \mathrm{~V}_{8}$ & $\mathrm{~V}_{8}$ & $\mathrm{~V}_{8}$ & \\
$\mathrm{~V}_{9}$ & $\mathrm{~V}_{9}$ & $\mathrm{~V}_{9}$ & $\mathrm{~V}_{9}$ & $\mathrm{~L}_{2}$ \\
\hline
\end{tabular}

Table B5. Level partition - Iteration 3

\begin{tabular}{lllll}
\hline $\mathrm{V}_{i}$ & $S_{\boldsymbol{r}}$ & $\mathrm{S}_{\boldsymbol{a}}$ & $\mathrm{S}_{i}$ & $\mathrm{~L}_{i}$ \\
\hline $\mathrm{V}_{1}$ & $\mathrm{~V}_{1}$ & $\mathrm{~V}_{1}$ & $\mathrm{~V}_{1}$ & $\mathrm{~L}_{3}$ \\
$\mathrm{~V}_{3}$ & $\mathrm{~V}_{3}, \mathrm{~V}_{5}$ & $\mathrm{~V}_{3}$ & $\mathrm{~V}_{3}$ & \\
$\mathrm{~V}_{5}$ & $\mathrm{~V}_{5}$ & $\mathrm{~V}_{3}, \mathrm{~V}_{5}, \mathrm{~V}_{6}, \mathrm{~V}_{7}, \mathrm{~V}_{8}$ & $\mathrm{~V}_{5}$ & $\mathrm{~L}_{3}$ \\
$\mathrm{~V}_{6}$ & $\mathrm{~V}_{5}, \mathrm{~V}_{6}$ & $\mathrm{~V}_{6}, \mathrm{~V}_{7}, \mathrm{~V}_{8}$ & $\mathrm{~V}_{6}$ & \\
$\mathrm{~V}_{7}$ & $\mathrm{~V}_{5}, \mathrm{~V}_{6}, \mathrm{~V}_{7}$ & $\mathrm{~V}_{7}$ & $\mathrm{~V}_{7}$ & \\
$\mathrm{~V}_{8}$ & $\mathrm{~V}_{5}, \mathrm{~V}_{6}, \mathrm{~V}_{8}$ & $\mathrm{~V}_{8}$ & $\mathrm{~V}_{8}$ & \\
\hline
\end{tabular}

Table B6. Level partition - Iteration 4

\begin{tabular}{lllll}
\hline $\mathrm{V}_{i}$ & $S_{r}$ & $S_{a}$ & $\mathrm{~S}_{i}$ & $\mathrm{~L}_{i}$ \\
\hline $\mathrm{V}_{3}$ & $\mathrm{~V}_{3}$ & $\mathrm{~V}_{3}$ & $\mathrm{~V}_{3}$ & $\mathrm{~L}_{4}$ \\
$\mathrm{~V}_{6}$ & $\mathrm{~V}_{6}$ & $\mathrm{~V}_{6}, \mathrm{~V}_{7}, \mathrm{~V}_{8}$ & $\mathrm{~V}_{6}$ & $\mathrm{~L}_{4}$ \\
$\mathrm{~V}_{7}$ & $\mathrm{~V}_{6}, \mathrm{~V}_{7}$ & $\mathrm{~V}_{7}$ & $\mathrm{~V}_{7}$ & \\
$\mathrm{~V}_{8}$ & $\mathrm{~V}_{6}, \mathrm{~V}_{8}$ & $\mathrm{~V}_{8}$ & $\mathrm{~V}_{8}$ & \\
\hline
\end{tabular}

Table B7. Level partition - Iteration 5

\begin{tabular}{lllll}
\hline $\mathrm{V}_{i}$ & $S_{r}$ & $S_{a}$ & $\mathrm{~S}_{i}$ & $\mathrm{~L}_{i}$ \\
\hline $\mathrm{V}_{7}$ & $\mathrm{~V}_{7}$ & $\mathrm{~V}_{7}$ & $\mathrm{~V}_{7}$ & $\mathrm{~L}_{5}$ \\
$\mathrm{~V}_{8}$ & $\mathrm{~V}_{8}$ & $\mathrm{~V}_{8}$ & $\mathrm{~V}_{8}$ & $\mathrm{~L}_{5}$ \\
\hline
\end{tabular}




\section{References}

Ahmad M, Tang X-W, Qiu J-N, Ahmad F (2019a) Evaluating Seismic Soil Liquefaction Potential Using Bayesian Belief Network and C4. 5 Decision Tree Approaches Applied Sciences 9:4226

Ahmad M, Tang X-W, Qiu J-N, Ahmad F (2019b) Interpretive Structural Modeling and MICMAC Analysis for Identifying and Benchmarking Significant Factors of Seismic Soil Liquefaction Applied Sciences 9:233

Ahmad M, Tang X-W, Qiu J-N, Ahmad F, Gu W-J (2020a) A step forward towards a comprehensive framework for assessing liquefaction land damage vulnerability: Exploration from historical data Frontiers of Structural and Civil Engineering:116

Ahmad M, Tang X-W, Qiu J-N, Gu W-J, Ahmad F (2020b) A hybrid approach for evaluating CPT-based seismic soil liquefaction potential using Bayesian belief networks Journal of Central South University 27:500-516

Boulanger R, Idriss I (2014) CPT and SPT based liquefaction triggering procedures vol 1.

Breiman L (2001) Random forests Machine learning 45:5-32

Castelletti A, Soncini-Sessa R (2007) Bayesian Networks and participatory modelling in water resource management Environ Model Software 22:1075-1088

Ghribi A, Masmoudi A (2013) A compound poisson model for learning discrete Bayesian networks Acta Mathematica Scientia 33:1767-1784

Goh AT (1996) Neural-network modeling of CPT seismic liquefaction data Journal of Geotechnical Engineering 122:70-73

Goh AT, Goh S (2007) Support vector machines: their use in geotechnical engineering as illustrated using seismic liquefaction data Computers and Geotechnics 34:410421

Hosmer DW, Lemeshow S (2000) Applied Logistic Regression. John Wiley \& Sons New York

Hu J-L, Tang X-W, Qiu J-N (2015) A Bayesian network approach for predicting seismic liquefaction based on interpretive structural modeling Georisk: Assessment and Management of Risk for Engineered Systems and Geohazards 9:200-217

Idriss I, Boulanger R (2006) Semi-empirical procedures for evaluating liquefaction potential during earthquakes Soil Dyn Earthquake Eng 26:115-130

John G, Langley P (1995) Estimating Continuous Distributions in Bayesian Classifiers. In proceedings of the Eleventh Conference on Uncertainty in Artificial Intelligence. Morgan Kaufmann Publishers. San Matco,

Joseph SA, Adams BJ, McCabe B (2010) Methodology for Bayesian belief network development to facilitate compliance with water quality regulations J Infrastruct Syst 16:58-65 
Juang $\mathrm{CH}$, Yuan $\mathrm{H}$, Lee D-H, Lin P-S (2003) Simplified cone penetration test-based method for evaluating liquefaction resistance of soils Journal of Geotechnical and Geoenvironmental Engineering 129:66-80

Kabir G, Tesfamariam S, Francisque A, Sadiq R (2015) Evaluating risk of water mains failure using a Bayesian belief network model European Journal of Operational Research 240:220-234

Kohestani V, Hassanlourad M, Ardakani A (2015) Evaluation of liquefaction potential based on CPT data using random forest Nat Hazards 79:1079-1089

Masmoudi K, Abid L, Masmoudi A (2019) Credit risk modeling using Bayesian network with a latent variable Expert Systems with Applications 127:157-166

Moss R, Seed RB, Kayen RE, Stewart JP, Der Kiureghian A, Cetin KO (2006) CPT-based probabilistic and deterministic assessment of in situ seismic soil liquefaction potential Journal of Geotechnical and Geoenvironmental Engineering 132:10321051

Nadkarni S, Shenoy PP (2001) A Bayesian network approach to making inferences in causal maps European Journal of Operational Research 128:479-498

Okoli C, Schabram K (2010) A guide to conducting a systematic literature review of information systems research

Oommen T, Baise LG, Vogel R (2010) Validation and application of empirical liquefaction models Journal of Geotechnical and Geoenvironmental Engineering 136:1618-1633

Pal M (2006) Support vector machines-based modelling of seismic liquefaction potential International Journal for Numerical and Analytical Methods in Geomechanics 30:983-996

Pearl J (1988) Probabilistic reasoning in intelligent systems: Representation \& reasoning. Morgan Kaufmann Publishers; San Mateo, CA

Raj T, Attri R (2011) Identification and modelling of barriers in the implementation of TQM International Journal of Productivity and Quality Management 8:153-179

Ravi V, Shankar R (2005) Analysis of interactions among the barriers of reverse logistics Technol Forecast Soc Change 72:1011-1029

Robertson PK, Wride C (1998) Evaluating cyclic liquefaction potential using the cone penetration test Canadian geotechnical journal 35:442-459

Sage AP (1977) Methodology for large-scale systems

Samui P (2007) Seismic liquefaction potential assessment by using relevance vector machine Earthquake Engineering and Engineering Vibration 6:331-336

Samui P, Sitharam T, Contadakis M (2011) Machine learning modelling for predicting soil liquefaction susceptibility Natural Hazards \& Earth System Sciences 11

Seed HB, Idriss I Evaluation of liquefaction potential sand deposits based on observation of performance in previous earthquakes. In: ASCE national convention (MO), 1981. pp 481-544 
Seed HB, Idriss IM (1971) Simplified procedure for evaluating soil liquefaction potential Journal of Soil Mechanics \& Foundations Div

Shankar R, Narain R, Agarwal A (2003) An interpretive structural modeling of knowledge management in engineering industries Journal of Advances in Management Research

Tranfield D, Denyer D, Smart P (2003) Towards a methodology for developing evidence-informed management knowledge by means of systematic review $\mathrm{Br} \mathrm{J}$ Manage 14:207-222

Vapnik VN (1995) The nature of statistical learning Theory

Warfield JN (1974) Developing interconnection matrices in structural modeling IEEE Transactions on Systems, Man, and Cybernetics SMC-4:81-87

Xue X, Yang X (2013) Application of the adaptive neuro-fuzzy inference system for prediction of soil liquefaction Nat Hazards 67:901-917

Youd TL, Idriss IM (2001) Liquefaction resistance of soils: summary report from the 1996 NCEER and 1998 NCEER/NSF workshops on evaluation of liquefaction resistance of soils Journal of Geotechnical and Geoenvironmental Engineering 127:297-313

Zhang L (1998) Predicting seismic liquefaction potential of sands by optimum seeking method Soil Dyn Earthquake Eng 17:219-226 
Figures

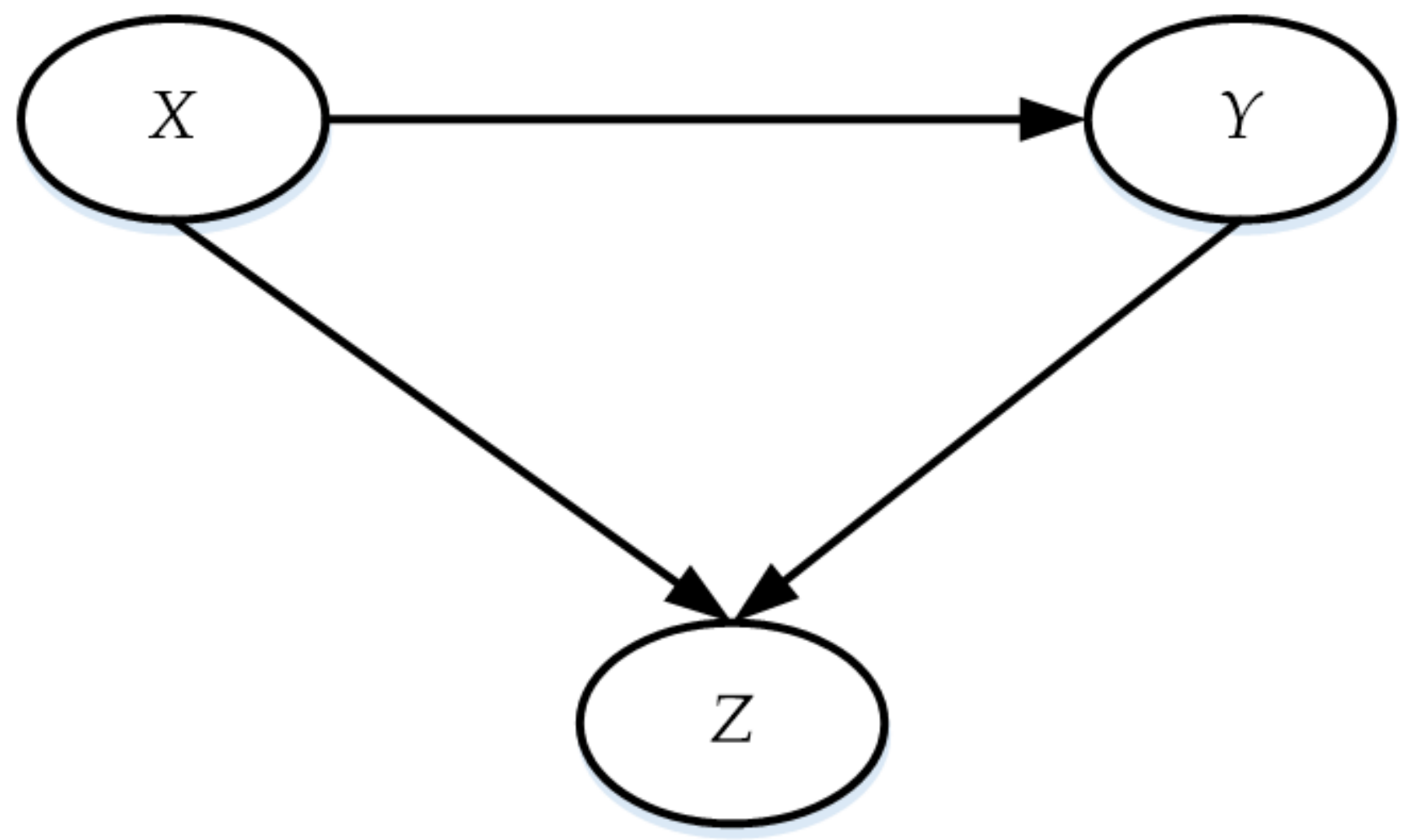

Figure 1

A simple Bayesian Network structure. 


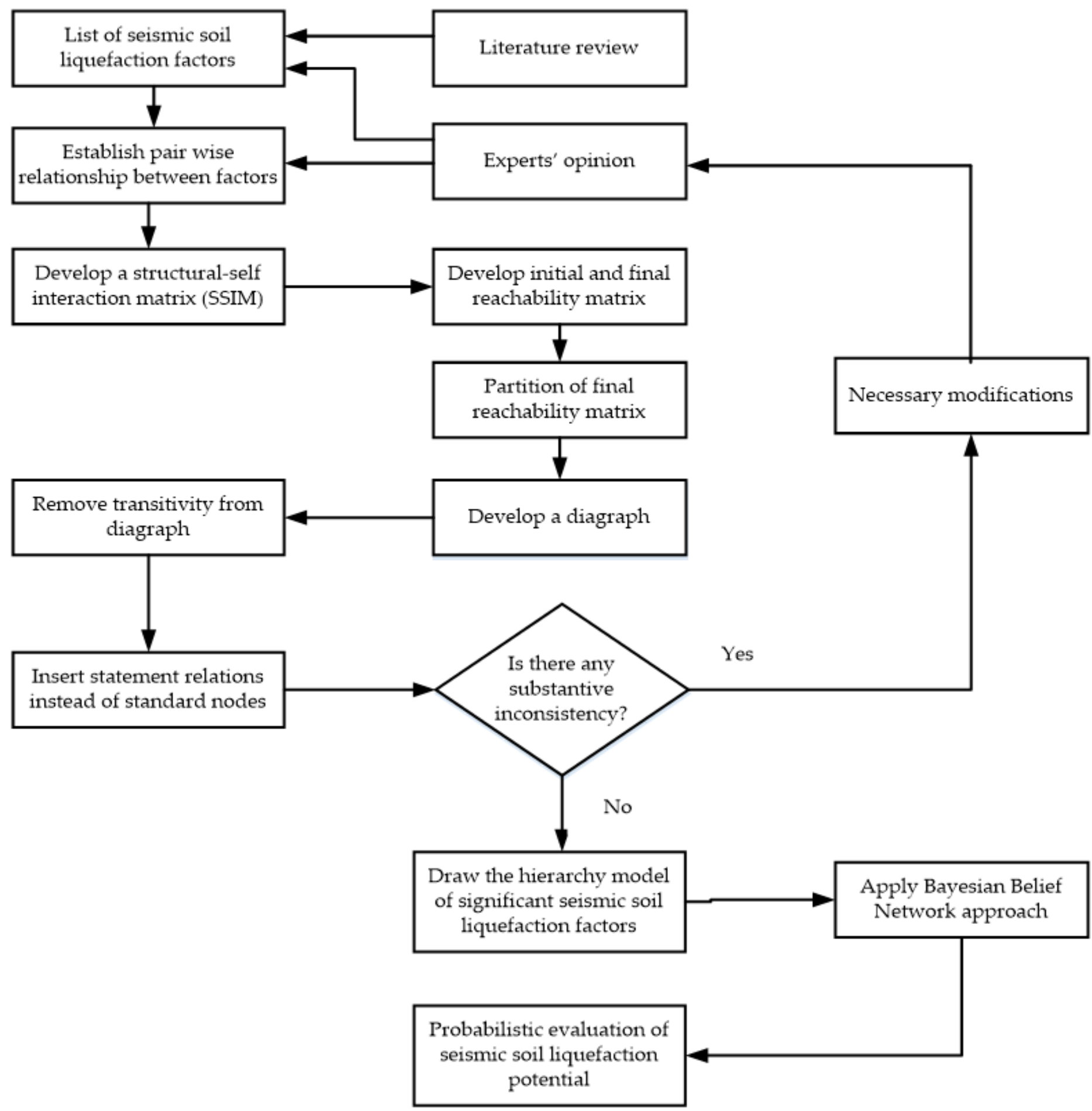

Figure 2

The process outline of the methodology of research used in the present study. 

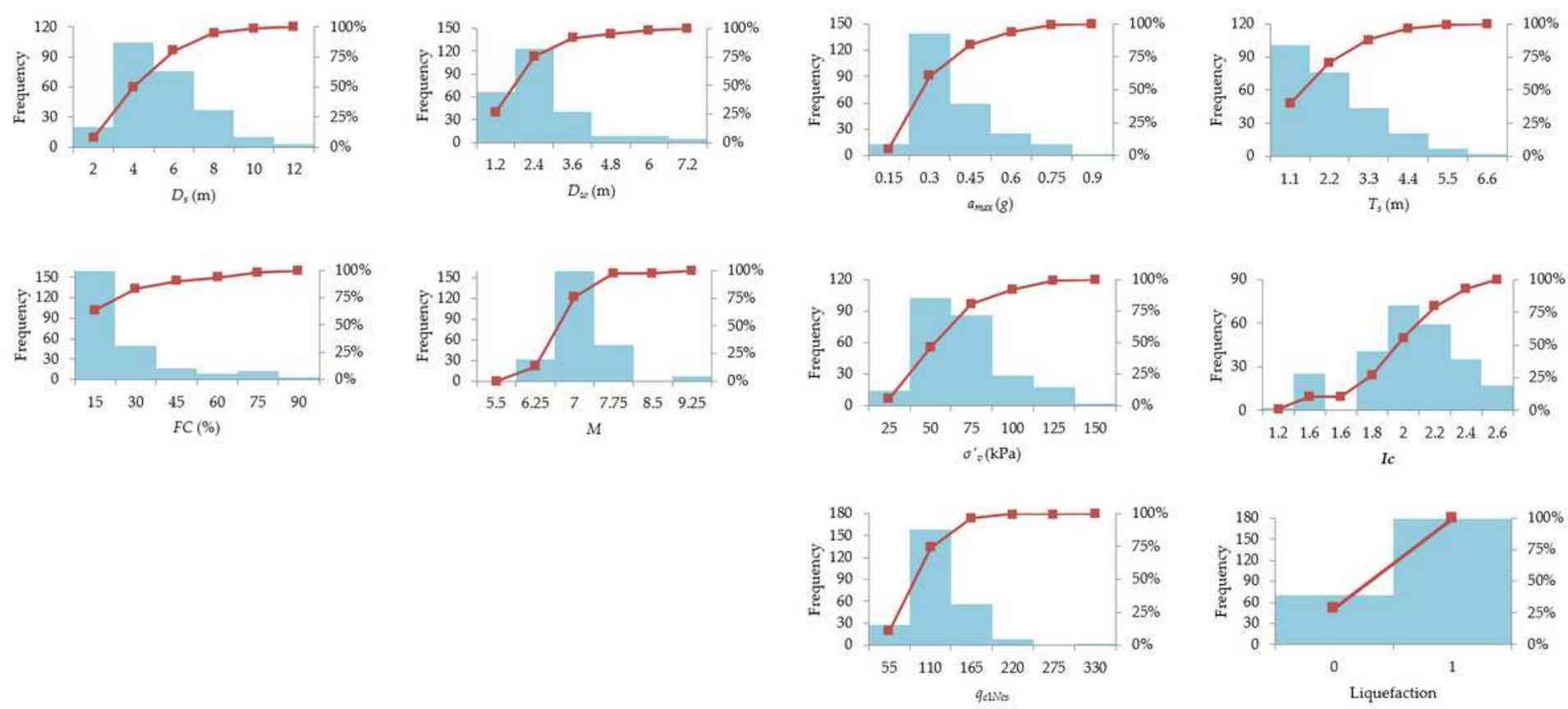

Figure 3

Frequency histograms of measured parameters 


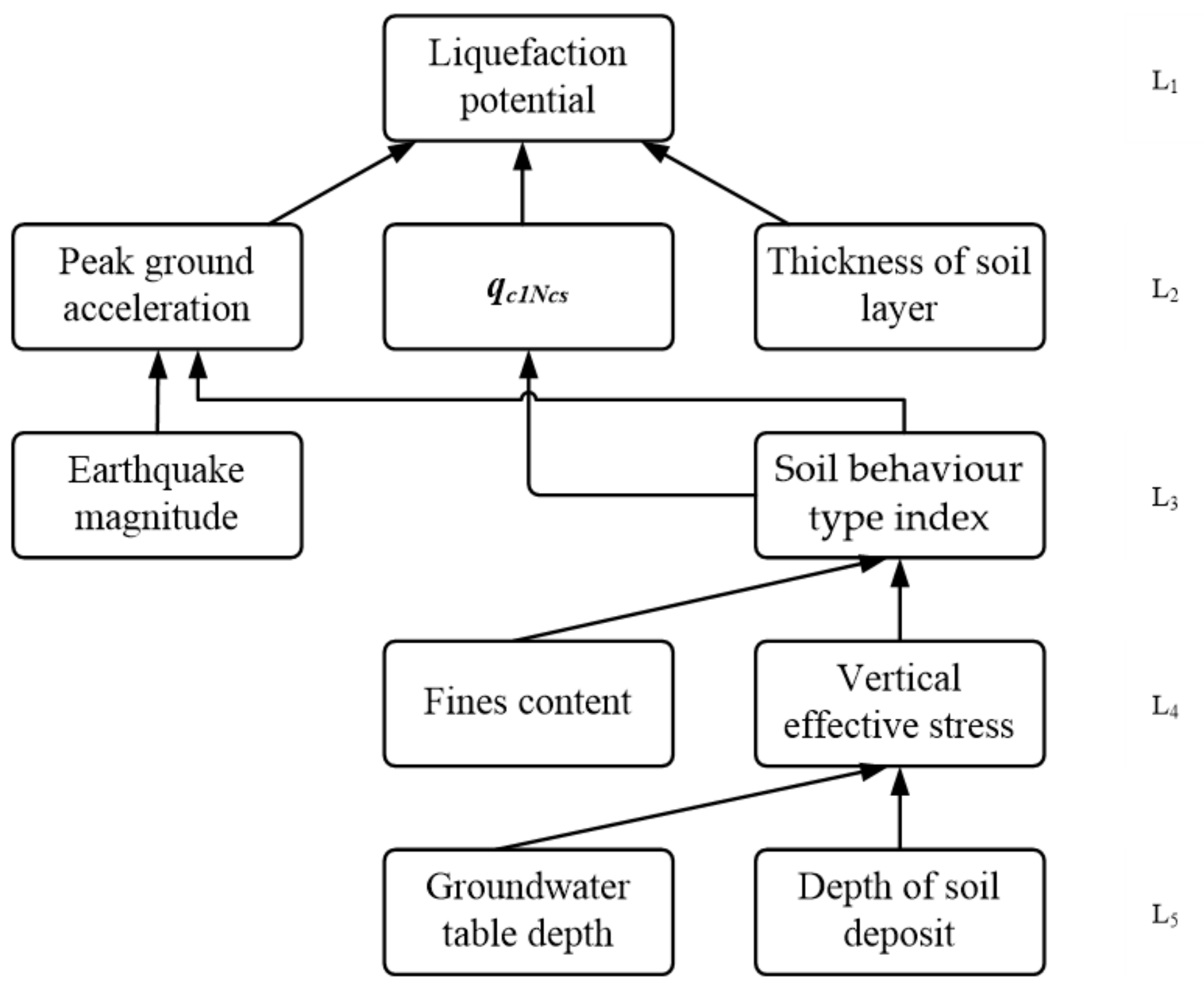

Figure 4

Interpretive structural modeling of liquefaction potential. 


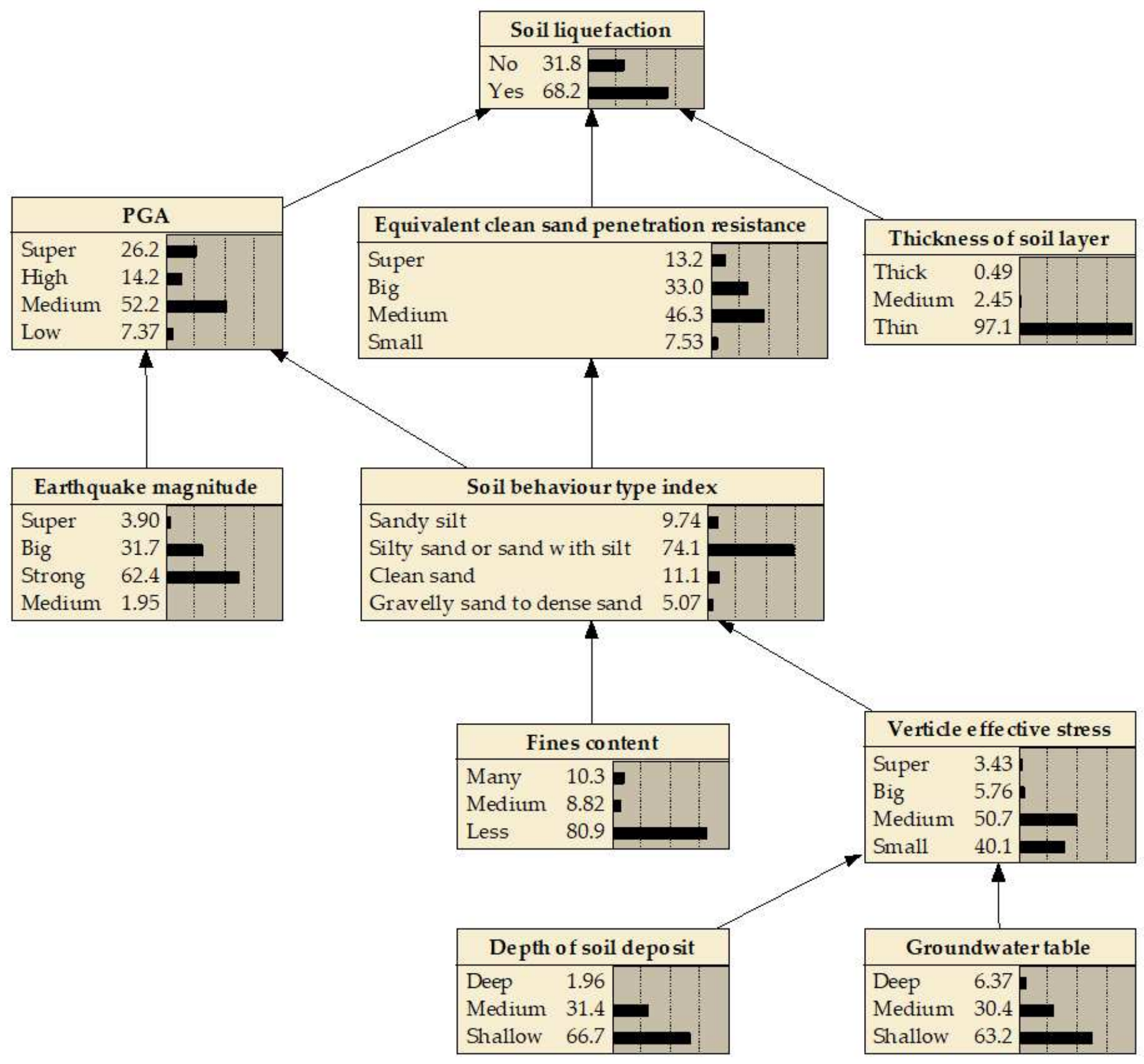

Figure 5

Liquefaction potential graphical model. 


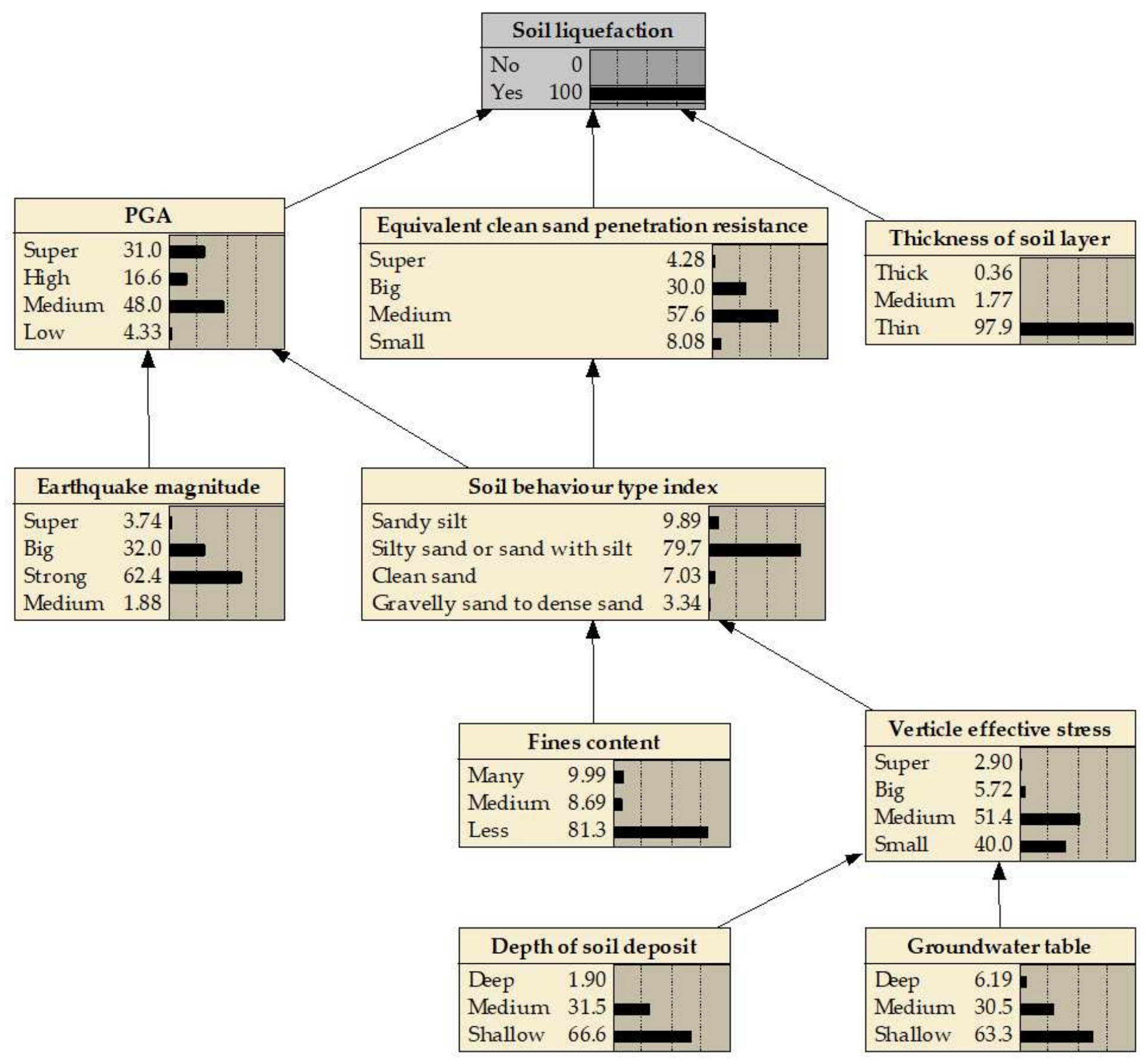

Figure 6

MPE of seismic soil liquefaction. 